Article

\title{
Forest Cover and Sustainable Development in the Lumbini Province, Nepal: Past, Present and Future
}

\author{
Bhagawat Rimal $^{1, *}$, Hamidreza Keshtkar ${ }^{2} \mathbb{D}$, Nigel Stork ${ }^{3}(\mathbb{D})$ and Sushila Rijal $^{4}(\mathbb{D}$ \\ 1 College of Applied Sciences, (CAS)-Nepal, Tribhuvan University, Kathmandu 44613, Nepal \\ 2 Department of Arid and Mountainous Regions Reclamation, Faculty of Natural Resources, University of \\ Tehran, Karaj 3158777871, Iran; Hkeshtkar@ut.ac.ir \\ 3 Centre for Planetary Health and Food Security, Griffith School of Environment and Science, \\ Griffith University, Nathan, QLD 4111, Australia; nigel.stork@griffith.edu.au \\ 4 Department of Environmental Management, Prince of Songkla University, Hat Yai 90112, Thailand; \\ 6210930019@email.psu.ac.th or sushilarijal2001@gmail.com \\ * Correspondence: author: bhagawat.rimal@casnepal.edu.np or bhagawatrimal@gmail.com
}

Citation: Rimal, B.; Keshtkar, H.; Stork, N.; Rijal, S. Forest Cover and Sustainable Development in the Lumbini Province, Nepal: Past, Present and Future. Remote Sens. 2021 13, 4093. https://doi.org/10.3390/ rs13204093

Academic Editors: Bingfang Wu, Yuan Zeng and Dan Zhao

Received: 1 September 2021

Accepted: 7 October 2021

Published: 13 October 2021

Publisher's Note: MDPI stays neutral with regard to jurisdictional claims in published maps and institutional affiliations.

Copyright: (c) 2021 by the authors. Licensee MDPI, Basel, Switzerland. This article is an open access article distributed under the terms and conditions of the Creative Commons Attribution (CC BY) license (https:/ / creativecommons.org/licenses/by/ $4.0 /)$.

\begin{abstract}
The analysis of forest cover change at different scales is an increasingly important research topic in environmental studies. Forest Landscape Restoration (FLR) is an integrated approach to manage and restore forests across various landscapes and environments. Such restoration helps to meet the targets of Sustainable Development Goal (SDG)-15, as outlined in the UN Environment's sixth Global Outlook, which includes the sustainable management of forests, the control of desertification, reducing degradation, biodiversity loss, and the conservation of mountain ecosystems. Here, we have used time series Landsat images from 1996 to 2016 to see how land use, and in particular forest cover, have changed between 1996 and 2016 in the Lumbini Province of Nepal. In addition, we simulated projections of land cover (LC) and forest cover change for the years 2026 and 2036 using a hybrid cellular automata Markov chain (CA-Markov) model. We found that the overall forest area increased by $199 \mathrm{~km}^{2}$ (2.1\%), from a $9491 \mathrm{~km}^{2}(49.3 \%)$ area in 1996 to $9691 \mathrm{~km}^{2}(50.3 \%)$ area in 2016. Our modeling suggests that forest area will increase by $81 \mathrm{~km}^{2}$ (9691 to $9772 \mathrm{~km}^{2}$ ) in 2026 and by $195 \mathrm{~km}^{2}\left(9772 \mathrm{~km}^{2}\right.$ to $\left.9966 \mathrm{~km}^{2}\right)$ in 2036. They are policy, planning, management factors and further strategies to aid forest regeneration. Clear legal frameworks and coherent policies are required to support sustainable forest management programs. This research may support the targets of the Sustainable Development Goals (SDG), the land degradation neutral world (LDN), and the UN decade 2021-2031 for ecosystem restoration.
\end{abstract}

Keywords: land cover (LC) change; forest management; forest restoration; Lumbini Province; Nepal

\section{Introduction}

Forest ecosystems are vital sources of food, medicine, and fuel for human beings. Achieving sustainable forest management is an important step in the transition towards sustainable development as well as for providing economic, social, and environmental outputs [1]. Global forest coverage of the Earth's terrestrial surface declined from 31.6\% to $30.6 \%$ between 1990 and 2015 [2], and every year, 10 million hectares (ha) of forest are lost [3]. To maintain a sustainable environment, regeneration and reforestation programs have become a top priority globally [4,5]. The Global 2030 Agenda for Sustainable Development Goals (SDG 15) was accepted by all countries [6]. The 15th SDG aims to "Protect, restore and promote the use of terrestrial ecosystems, environmental conservation, sustainably manage forest resource, combat desertification and halt and reverse land degradation and biodiversity loss" and has prioritized the monitoring of forests and the sustainable management of forest resources. It further endorses the guarantee of resilient agricultural practice, sustainable food production, and imaginative use of natural resources [7]. Many countries have collectively committed to restore 150 million ha of degraded land by 2020 
in Bonn Challenges, and an additional 350 million ha forest by 2030 based on the New York Declaration on Forests [8]. IUCN and the Worldwide Fund for Nature (WWF) first proposed the Forest Landscape Restoration (FLR) initiative at the beginning of the 21st century. The United Nations Framework Convention on Climate Change (UNFCCC), the UN Framework Convention to Combat Desertification (UNCCD), the SDGs, the Rio+20 Land Degradation Neutrality (LDN) as well as the Reducing Emissions from Deforestation and Forest Degradation (REDD+) programs all make restoring degraded landscape through FLR a priority [8]. The United Nations has highlighted ecosystem restoration as part of the decade 2021-2031 [9]. The Forest and Landscape Restoration Mechanism (FLRM) was introduced by FAO to monitor and report on forest landscape restoration [2] and targets a sustainable future environment with improved ecological functionality [5]. This approach was introduced in the 2000s, and its background was set during the Earth Summit in 1992. In Asia, forests increased by more than 1.2 million ha during 2010-2020 [10], as several countries are setting ambitious targets. For example, India launched a program to increase its forests by an 8 million ha area by 2030 [11]. Similarly, South Korea, Vietnam, Indonesia, and China have launched forest restoration programs [12,13], with the Grain to Green Program (GTGP) being introduced in China [14]. In the region of sub-Saharan African, 30 countries joined together in the African Forest Landscape Restoration Initiative, pledging 100 million ha in FLR targets by early April, 2020 [15]. Forest restoration in the Netherlands was the combined effort of actions by the private sector and the government. In Europe, forest landscape restoration is largely an outcome of the nineteenth century's restoration activities $[16,17]$.

In Nepal, forest resources, which had been severely degraded during the 1960-1970s, had substantially improved from a total stem volume of 880 million metric tons in 1990 to 897 million metric tons by $2005[18,19]$ and to 982 million cubic meters and an average growing stock of 164.76 cubic meter per ha by 2015 [20]. National forest cover increased from 38\% in 1978-1979 (Land resource mapping project-LRMP) to $40.36 \%$ by 2015 (excluding shrub land) [20]. The annual deforestation rate reduced from $1.31 \%$ during the period of $1930-1975$ to $0.51 \%$ in the period of $1975-1985$, before falling to $0.14 \%$ from $1985-1995$, $0.1 \%$ from $1995-2005$, and stabilizing at $0.01 \%$ from 2005-2014 [21]. To conserve forests and to enhance livelihoods [22], Community Forest User Groups (CFUGs) [23-25] were formed under the legal provisions of Forest Act, 1993 [26], and the Forest Regulation Act, 1995 [27]. Since 1993, Nepal has gradually handed over large portions of national forest to local communities, mainly in the hill areas of the country [28]. Similarly, the Government of Nepal introduced a forestry decade (2014-2024) with the motto of "one house one tree, one village one forest, one city several gardens", which targets the restoration and plantation of a minimum of 26,000 ha in the Tarai, Siwalik, and hill regions. The Ecosystem-Based Adaptation (EbA) approach regards ecosystem services as an integral part of adaptation strategies to address the impacts of climate change [29]. The UN REDD+ program emphasizes the economic benefits obtained from carbon stocks in forests [30], and the REDD+ results-oriented payments approach for the achievements in forest and land use cluster is widely accepted and used by many developing countries, including Nepal [31]. The REDD+ performance-based payment mechanism through the World Bank's Forest Carbon Partnership Facilities' (FCPA) Carbon Fund (CF) agreed to provide USD 45 million to Nepal for to reduce carbon emissions and to prevent deforestation and forest degradation by 2025 in the period from June 2018 to December 2024. Nepal is expected to reduce emissions by 9 million tons of carbon through forest conservation in the Tarai Arc Landscape (TAL) [32].

The Constitution of Nepal 2015 also has provisions for the management of forest under federal, provincial, local level governments for a diverse range of users [33] aims to conserve, promote, and sustainably use forest resources and biodiversity and minimize the adverse impacts of industrial and physical development. The Local Government Operation Act, 2017, mandates local governments to facilitate community-based forest management approaches to sustainably manage forests [28]. One example of this approach, the President Chure Tarai-Madhesh-Conservation Program, which was introduced in 2016, is expected 
to make a positive contribution in controlling forest degradation and protecting vulnerable landscapes [34]. Watershed management plans also contribute to landscape conservation and include slope management through terracing, trenching, and re/afforestation [35]. There are 118 ecosystem services have been recorded in Nepal [36]. The National Parks and Wildlife Conservation Act (1993), the fourth amendment, provisioned the investment of $30-50 \%$ of the total annual revenue of protected areas in local communities for biodiversity conservation and livelihood improvements [37]. Recently, local-level administrations have introduced urban plantation programs in urban areas, green road programs for major urban areas, and plantation programs in barren lands in rural areas of this region. All of these provide support for forest restoration, and we should expect forested area to continue to increase in the future. Private forest programs (PF) provide another option to increase the forested areas in Nepal [38] and are already in place in Lumbini Province. Against this backdrop, we attempted to extract land cover (LC) changes for the Lumbini Province of Nepal at decadal intervals from 1996 using remote sensing technology and to project future LC for the years 2026 and 2036 using an LC change simulation model.

Several studies have examined the spatiotemporal land use land cover (LULC) change of various parts of Nepal, such as the Sagarmatha National Park region during the period of 1992-2011 [39], in Kathmandu during the period of 1990-2010 [40], in the Tanahun district during the period of 1976-2015 [41], in Koshi river basin during the period of 1992-2010 [42], in the Bagmati river basin [43,44], and at the trans-boundary of the Gandaki river basin [45]. In this study, we have chosen Lumbini Province to complete the LC change analysis for several reasons. First, the forest in this region is the dominant LC in the Province, particularly in the northern belt, while the southern part of the study area comprises the rapidly urbanizing Tarai region, which is experiencing remarkable LULC changes. Since landscape changes and anthropogenic factors affect habitat quality and distribution [46,47], the monitoring of forest cover is crucial. Further, these socioeconomic and environmental factors have characterized the heterogeneous composition and overtime dynamics of forest cover. Third, to our knowledge, no other study has examined historical forest cover changes or has made predictions for future changes in the Lumbini Province of Nepal, and our research attempts to fill this gap. Understanding the dynamics of LULC and making reliable projections are imperative in resource governance and for improving land use [48] since forest resources and their management are essential for human well-being and for the maintenance of ecosystem services [49]. As such, the obtained research outputs will be the base for establishing the legal framework and for formulating coherent policies in support of the global targets of the Sustainable Development Goals (SDGs), the land degradation-neutral world (LDN), and the UN decade 2021-2031 for ecosystem restoration.

LC changes are a major driver of global environmental change and occur due to deforestation, reforestation, urban expansion, and the intensification of cultivated land [50,51]. LC change models can be used to predict the location and frequency of LC change [52]; to aid land use planning and conservation [53], urbanization [54,55], Lake area evaluation [56]; and to monitor environmental changes [57]. A number of simulation models are widely used, such as DINAMICA [53,58], SLEUTH [59], SERGoM [60], CLUE [61], GEOMOD [62], LUCAS [63] ANN-CA [64], and the CA-Markov change model [65-68]. Here, we evaluate past landscape change and predict future changes in forests and built-up areas. We use the Cellular Automata (CA)-Markov chain (MC) (CA-Markov) model, as these models appear to be excellent at predicting future LC changes and transitions [69] due to its strong hybrid functions [70].

\section{Methodology}

\subsection{Study Area}

Lumbini Province is located in Western Nepal and is geographically located between 81.10-84.072 E to $27323-28.833 \mathrm{~N}$, covering about $19,256 \mathrm{~km}^{2}$. Elevation ranges from $\pm 90 \mathrm{~m}$ to $5600 \mathrm{~m}$ above sea level (masl). It includes a total of 12 administrative districts (six in Tarai and six in Hill region), covering 109 local administrative units. The total population 
of this Province was 3.45 million in 1991 and 4.96 million in 2011 (CBS, 2014). We have chosen Lumbini Province as the subject for the LC change analysis, as the Province has integrated national parks, hunting reserves, and conservation areas (Banke National Park, Bardiya National Park, the Dhor Patan hunting reserve, and the Krishnasar conservation areas) (Figure 1). It also includes Jagdishpur, a Ramsar-listed lake, and Lumbini, the birthplace of Lord Gautam Buddha-a place listed as a UNESCO World Heritage site in 1997. Additionally, Devdaha lake, the Anoma river, the Jitgadh fort, Tansen, and Ridi Ruru are also located within the Province.

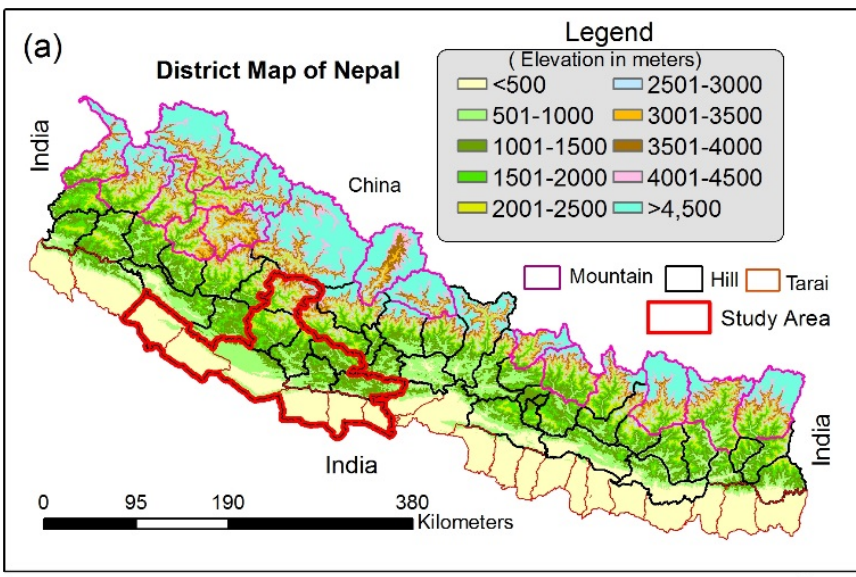

Population Distribution of Study Area, 1991-2011
\begin{tabular}{|l|r|r|l|l|}
\hline DISTRICT & 1991 & 2001 & $\mathbf{2 0 1 1}$ Geo_REGION & $\begin{array}{l}\text { GAIN and LOSS } \\
\text { (2001-2011) }\end{array}$ \\
\hline ARGHAKHANCHI & 180884 & 208391 & 197632 HILL & LOSS \\
\hline BANKE & 285604 & 385840 & 491313 TERAI & GAIN \\
\hline BARDIYA & 290313 & 382649 & 426576 TERAI & GAIN \\
\hline DANG & 354413 & 462380 & 552583 TERAI & GAIN \\
\hline GULMI & 266331 & 296654 & 280160 HILL & LOSS \\
\hline KAPILBASTU & 371778 & 481976 & 571936 TERAI & GAIN \\
\hline NAWALPARASI & 436217 & 562870 & 643508 TERAI & GAIN \\
\hline PALPA & 236313 & 268558 & 261180 HILL & LOSS \\
\hline PYUTHAN & 175469 & 212484 & 228102 HILL & GAIN \\
\hline ROLPA & 179621 & 210004 & 224506 HILL & GAIN \\
\hline RUKUM & 155554 & 188438 & 208567 HILL & GAIN \\
\hline RUPANDEHI & 522150 & 708419 & 880196 TERAI & GAIN \\
\hline TOTAL & 3454647 & $\mathbf{4 3 6 8 6 6 3}$ & 4966259 & \\
\hline
\end{tabular}
* Population distribution of each district
represented before new administrative
(Including Nawalparasi and Rukum)
division of Nepal, 2017
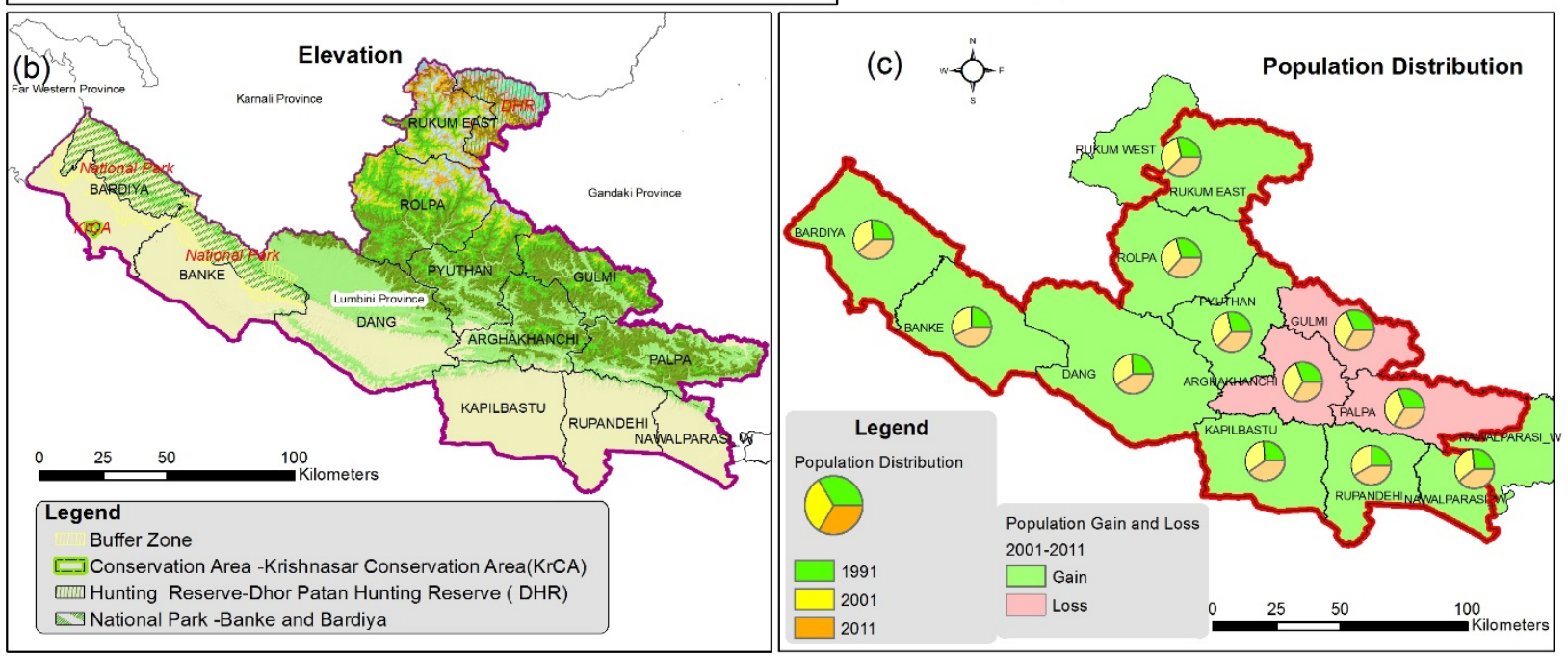

Figure 1. Location of the study area.

\subsection{Data}

In the study, we collected Landsat satellite Level 1 data (TM and OLI) for the years 1996, 2006, and 2016 from the USGS website (earthexplorer.usgs.gov) (Table 1). All of the images were verified for image processing. Radiometric correction of remote sensing data mainly involves the correction of digital image errors [71,72], where image enhancement and registration are conducted for image correction [72]. The L1T (level one terrain corrected) satellite images were converted from DN (digital number) to radiance. The digital number was converted, and the FLASH model and was applied for image processing using ENVI software. ENVI software is organized with radiance calibration, geometric, and atmospheric correction for satellite images. A root mean square (RMS) error of the geometric rectification images that was less than $0.5(<15 \mathrm{~m})$ pixels was accepted. A $30-\mathrm{m}$ shuttle radar topography mission (SRTM) digital elevation model (DEM) was used for the image registration for the years 1996, 2006 and 2016. 
Table 1. Satellite images.

\begin{tabular}{cccc}
\hline Path/Row & 1996 (Landsat 5 TM) & $\begin{array}{c}\text { 2006 (Landsat 5 TM } \\
\text { and ETM +) }\end{array}$ & 2016 (Landsat 8 OLI) \\
\hline $142 / 041$ & 10-November & 5-October TM & 1-November \\
\hline $143 / 040 / 41$ & 17-November & 2-March TM & 8-November \\
\hline $144 / 040$ & 10-December & 27-October-ETM+ (SLC, OFF) & 30-October \\
\hline
\end{tabular}

The overlay function was conducted to fill the no data gaps in the ETM+ scenes where the TM data were unavailable (Table 1). There are multiple methods that can be used to fill in the gaps of the SLC-off Landsat images for years after 2003. The local histogram matching method (LHMM) was applied by Storey et al. in 2005 [73]. Similarly, the geostatistical interpolation method is another option that can be used to fill in the gaps of missing data [74]. A further option, a deep convolution neural network (CNN) model, can also be used to recover missing information resulting from the SL-off problem [75]. To fill in the gaps of the SLC-off images, auxiliary images were used to recover the missing data [76]. In our study, a small part of the covered area comprised SLC-off images for 2006, so we collected the topographical data developed by the Survey Department of Nepal for the scale of 1:25,000 [77]. Similarly, the LC data for the year 2000 [78] and further verified satellite images (Landsat TM) got 2008, November Nine (11-09) were used to verify the LC information of the missing data. Additionally, we collected Google images of the study area for the year 2006, and this provided the best information for the missing data for the year 2006. After all of the available auxiliary images were verified, the classified satellite images for 2006 were overlaid with the corrected missing data, and the final LULC map of 2006 was prepared.

Topographical data developed by the Survey Department of Nepal, 1996, and Google Earth images were used as the reference data for the image classification [79] of the entire study area. For the extraction of the LC data, we used the modified LC classification scheme recommended in Anderson et al. [80] (Table 2) and explored nine major LC classes: agriculture, forest, shrub, grassland, sand, barren land, water bodies, ice and snow cover, and other areas (including settlement road networks, industrial areas, infrastructure, and other planned areas).

Table 2. LULC classification schemes.

\begin{tabular}{|c|c|}
\hline LULC Types & Description \\
\hline Cultivated land & Orchards, wet and dry crop lands \\
\hline Forest & $\begin{array}{c}\text { Evergreen broad leaf forest, deciduous forest, temperate forest, } \\
\text { low-density sparse forest, degraded forest, mix of trees, and other } \\
\text { natural covers }\end{array}$ \\
\hline Shrub & Mix of short trees, other natural covers, and highly degraded forest \\
\hline Barren land & Cliffs/small landslides, bare rocks, other unused land \\
\hline Sand & sandy areas, river banks, other areas \\
\hline Water & Reservoir, river, lake/pond, canal, and swamp areas \\
\hline Grass & $\begin{array}{l}\text { Mainly grass fields (dense coverage grass, moderate coverage grass, } \\
\text { and low coverage grass) }\end{array}$ \\
\hline Ice and snow cover & Perpetual/temporary snow cover, perpetual ice/glacier \\
\hline Other Areas & $\begin{array}{c}\text { Airports, public service areas (e.g., school, college, hospital, and } \\
\text { occupied areas), industrial areas, construction areas, residential areas } \\
\text { (urban and rural settlements), commercial areas, road networks, and } \\
\text { other areas }\end{array}$ \\
\hline
\end{tabular}


To extract the nine LC classes, all of the images for different tiles were stacked, subset, and analyzed using ENVI v5.3 software. We applied a non-parametric supervised support vector machine (SVM) to extract the LC for a specific area. A number of parametric and non-parametric algorithms [81] are frequently used for LC classification, such as minimum distance (MD), maximum likelihood (ML), support vector machines (SVM), artificial neural networks (ANN) and decision trees, and ML classifiers such as MD, BC, ANN, and fuzzy classification (FC) [82]. We applied supervised-learning SVM non-parametric and nonlinear approaches for the highly accurate extraction of LC change data $[79,83,84]$.

Generally, this approach is organized into four major kernels functions, such as polynominal, linear, radial, and sigmode. In this study, the radial basic function (RBF) kernel $[85,86]$ was applied with a 100 penalty parameter to be addressed in the ENVI software, and each kernel equation is listed in the following equations:

$$
\begin{gathered}
\text { Linear : } \mathrm{K}\left(x_{i}, y_{i}\right)=x_{i}^{T} \cdot x_{j} \\
\text { Polynomial : } \mathrm{K}\left(x_{i}, y_{i}\right)=\left(g \cdot x_{i}^{T} \cdot x_{j}+r\right)^{d}, g>0 \\
\text { Radial basis function : } \mathrm{K}\left(x_{i} y_{i}\right)=\mathrm{e}^{-g\left(x_{i}-x_{j}\right)^{2}}, g>0 \\
\text { Sigmoid : } \mathrm{K}\left(x_{i}, y_{i}\right)=\tan \mathrm{h}\left(g \cdot x_{i}^{T} \cdot x_{j}+r\right)
\end{gathered}
$$

where, $x_{i}, y_{i}$ are training vectors, and $g, d$, and $r$ are the user-controlled parameters of kernel function.

\subsection{Simulation of LC Change}

The CA-Markov hybrid approach is a suitable method for the simulation of LC change in places where cognition and characterizing landscape relationships are difficult [87]. This hybrid model has been widely used to effectively recognize and estimate landscape changes [88]. The CA-Markov model uses Markov chain matrices to identify the quantity of changes and Cellular Automata (CA) to spatially allocate these changes. The CA model addresses spatial allocation and the location of change via five parameters: (a) cell (b) neighborhood, (c) rules, (d) time, and (e) state [65,89]. In most cases, the steps of the CAMarkov model consist of [65]: (1) the classification of satellite images to generate LC maps; (2) the computing of transition area matrices; (3) the creation of transition potential images through driving parameters; (4) the estimation the model's capability to predict future changes based on evaluation indices; and (5) simulating the LC maps for future years.

The transition area matrix (TAM) was calculated using the Markov model. The TAM shows the number of pixels that are expected to shift from one LC type to another in the coming years. TAMs were calculated based on changes made in consecutive time periods (i.e., 1996-2006, 2006-2016, and 1996-2016) to show how each LC type was projected to shift. The TAM of 2006-2016 was used to simulate the LC projection to 2026, and the period of 1996-2016 was used to project the 2036 LC map.

The preparation of suitability maps is a difficult preliminary step in modeling LC change and depends on access to information and data [65]. In our study, the transition potential maps (TPMs) of LC types were prepared using multi-criteria evaluation (MCE), analytic hierarchy process (AHP) models, and fuzzy membership functions. The TPMs demonstrate the capacity of a cell to shift to a new category or to remain unchanged in each transition based on driving parameters [90]. In our study, the effective layers in the LC of the region, including slope, distance from roads, distance from water resources, distance from built-up areas, and distance from forest were chosen as the driving parameters based on the specialized knowledge and research history (e.g., $[65,87,91]$. The distance layers were standardized through the fuzzy membership method (Table 3). The factors were rescaled to special ranges (0-255) based on particular functions. Table 3 shows the standardization properties of the criteria for each factor. After standardization, all of the factors were weighed using the AHP method [88]. In this method, the factors are considered and compared in a pairwise form based on their relative importance for use. After all of the 
possible combinations are compared between the two factors, the module, weights, and consistency are calculated, and if the value is less than 0.1 , it means that the pairwise comparisons have an acceptable level of compatibility.

Table 3. Extracted weights based on AHP and fuzzy standardization.

\begin{tabular}{|c|c|c|c|c|}
\hline Factors & Suitability & Control Points & Functions & Weights \\
\hline Distance roads & $\begin{array}{l}\text { High } \\
\text { Medium } \\
\text { No }\end{array}$ & $\begin{array}{c}0-500 \mathrm{mts} \\
500-5000 \mathrm{mts} \\
>5000 \mathrm{mts}\end{array}$ & J-shaped & 0.25 \\
\hline Distance forests & $\begin{array}{l}\text { No } \\
\text { Medium } \\
\text { High }\end{array}$ & $\begin{array}{c}0-500 \mathrm{mts} \\
500-5000 \mathrm{mts} \\
>5000 \mathrm{mts}\end{array}$ & Linear & 0.12 \\
\hline Distance water bodies & $\begin{array}{c}\text { No } \\
\text { Medium } \\
\text { High }\end{array}$ & $\begin{array}{c}0-100 \mathrm{mts} \\
100-7500 \mathrm{mts} \\
>7500 \mathrm{mts}\end{array}$ & Linear & 0.12 \\
\hline Distance from Other area & $\begin{array}{l}\text { High } \\
\text { Medium } \\
\text { Low }\end{array}$ & $\begin{array}{c}0-100 \mathrm{mts} \\
100-5000 \\
>5000\end{array}$ & Linear & 0.35 \\
\hline Slope & $\begin{array}{l}\text { High } \\
\text { Medium } \\
\text { No }\end{array}$ & $\begin{array}{c}0 \% \\
0-15 \% \\
>15 \%\end{array}$ & Sigmoid & 0.16 \\
\hline
\end{tabular}

\subsection{Land-Cover Modeling and Validation}

In order to validate the CA-Markov model, the simulated LC map of the year 2016 was compared with the real map obtained from the classification of the satellite images from that year [92]. An accuracy of more than $80 \%$ indicates the model's simulation capability. The model was verified using several kappa variables: Klocation (the location accuracy of pixels in the simulation), Kstandard (a criterion of the ability of the model to achieve a complete classification), and Kno (the number of correctly classified pixels compared to the pixels that are expected to be classified correctly, without considering the quantity or the location error [65]. Therefore, researchers consider the Kno as a modified and more reliable version of Kstandard. The two indices-quantity disagreement and allocation disagreement, suggested by Pontius and Millones [93] — were also calculated and analyzed.

\subsection{Accuracy Assessment}

Accuracy assessment is one of the most fundamental tasks when LC data are prepared using remote sensing tools [94-96]. However, there is a challenge to find high-resolution data that can be used for the accuracy assessment. In this study, a total of 2844 sample points were designed for each of the LC-classified images for the years 1996, 2006, and 2016. A minimum of 300 sample points for each LC class and the user accuracy (UA), producer accuracy (PA), and overall accuracy (OA) were identified. The accuracy assessment of the classified images was prepared based on GPS points that had been collected from field observations using topographical maps developed by the Survey Department, 1998 (scale 1:25,000 and 1:50,000) [77], and high resolution Google Earth images (http:/ / earth.google. com, accessed on 30 August 2021). The overall accuracy of the results obtained for the individual years were 85.61\% (1996), 84.95\% (2006), and 86.91\% (2016).

\section{Results}

\subsection{LC Dynamics}

Over the period of 1996-2016, remarkable LC changes were observed. The areas of other land, mainly settlement areas, increased, particularly in the second decade. Forest cover decreased slightly in the first period but increased in the second, whereas shrub land showed the opposite trends. Changes in the barren land, water body, sand, and grassland areas were minimal. Small parts of the northern area fluctuated among ice and snow 
cover, barren land, and grassland. Decreases in ice and snow cover resulted in increases in grassland and barren land in the highlands of Nepal. Overall, other areas increased by $18.09 \%$ from 1996 to 2006 and by $55.70 \%$ from 2006 to 2016 . Cultivated land declined by $0.57 \%$ and $1.20 \%$, respectively, in the same periods. Forest cover area decreased by $0.46 \%$ during 1996-2006 but increased by 2.58\% between 2006 and2016. However, shrub land increased by $7 \%$ and by $28.46 \%$ during the same time periods. Water body and sand areas fluctuated due to changes in rainfall patterns. The ice and snow cover gradually decreased by $45.61 \%$ during the period of $1996-2006$ and by $35.39 \%$ during the period of $2006-2016$ (Table 4 and Figures 2 and 3).

Table 4. Distributions of LULC change between 1996 and 2016.

\begin{tabular}{|c|c|c|c|c|c|c|c|c|}
\hline LC Classes & 1996 & $\%$ & 2006 & $\%$ & $\begin{array}{l}\text { Change in \% } \\
(1996-2006)\end{array}$ & 2016 & $\%$ & $\begin{array}{c}\text { Change in \% } \\
(2006-2016)\end{array}$ \\
\hline Other Area & 183.24 & 0.95 & 216.38 & 1.12 & 18.09 & 336.9 & 1.75 & 55.7 \\
\hline Cultivated Land & 6542.50 & 33.98 & 6504.93 & 33.78 & -0.57 & 6426.91 & 33.38 & -1.2 \\
\hline Forest Land & 9491.65 & 49.29 & 9447.80 & 49.06 & -0.46 & 9691.15 & 50.33 & 2.58 \\
\hline Shrub Land & 1248.76 & 6.49 & 1339.45 & 6.96 & 7.26 & 958.28 & 4.98 & -28.46 \\
\hline Barren Land & 291.07 & 1.51 & 334.08 & 1.73 & 14.77 & 350.25 & 1.82 & 4.84 \\
\hline Sand & 476.27 & 2.47 & 556.36 & 2.89 & 16.82 & 476.98 & 2.48 & -14.27 \\
\hline Water body & 272.99 & 1.42 & 302 & 1.57 & 10.62 & 310 & 1.61 & 2.65 \\
\hline Grassland & 596.36 & 3.10 & 471.99 & 2.45 & -20.86 & 652.08 & 3.39 & 38.16 \\
\hline Ice and snow cover & 153.7 & 0.80 & 83.6 & 0.43 & -45.61 & 54.01 & 0.28 & -35.39 \\
\hline Total & $19,256.00$ & 100 & $19,256.00$ & 100 & & $19,256.00$ & 100 & \\
\hline
\end{tabular}

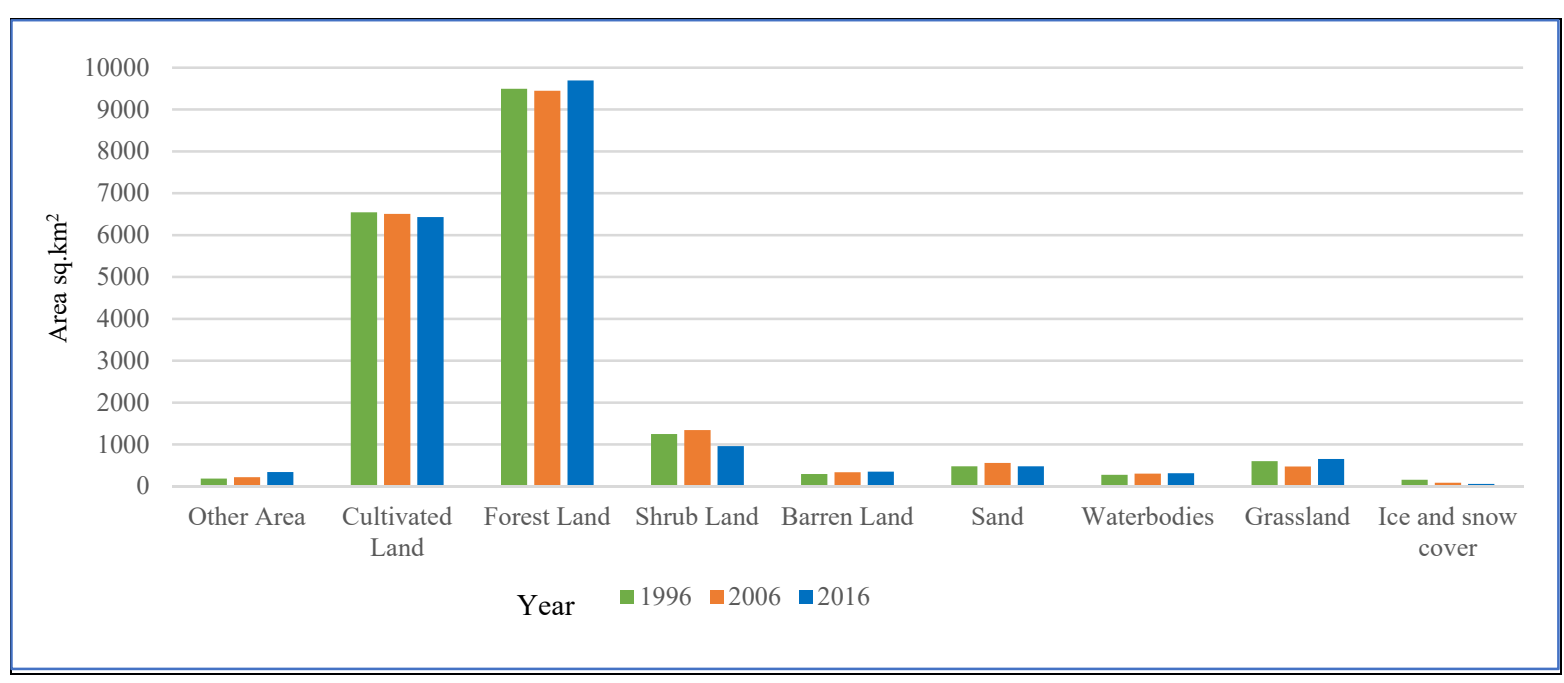

Figure 2. LC change trends in the study area, 1996-2016.
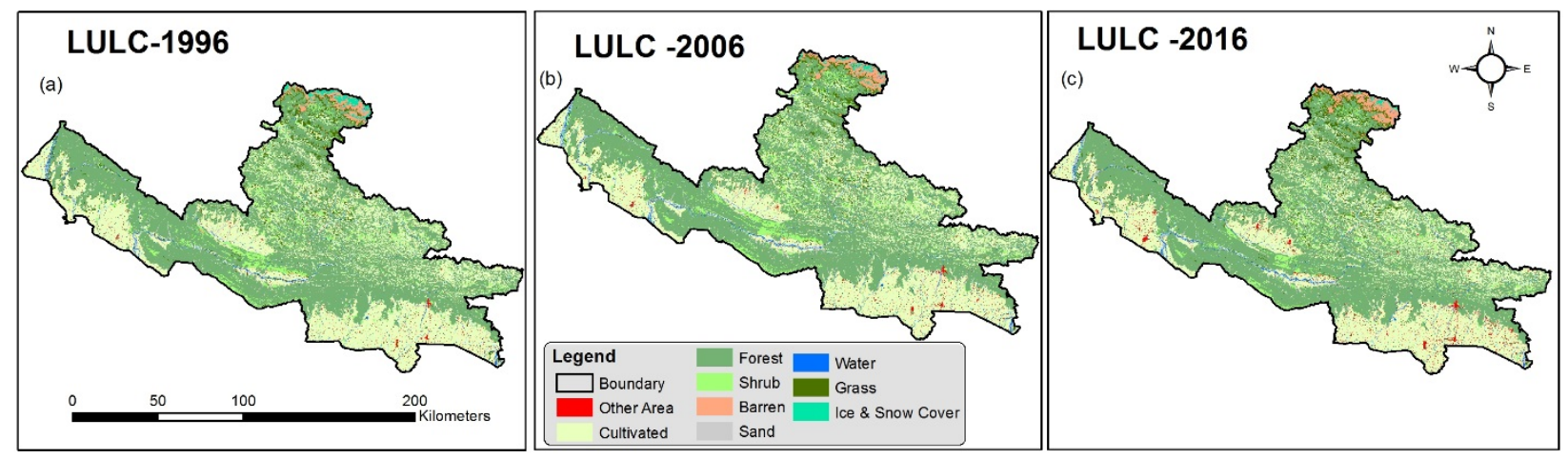

Figure 3. LC map of Lumbini Province (a) 1996; (b) 2006; (c) 2016. 


\subsection{Spatial Transitions}

The gains and losses of different LULC in different classes between 1996 and 2006 are presented in Table 5. Other areas(including settlements) increased by $18.09 \%$, from $183.24 \mathrm{~km}^{2}$ to $216.38 \mathrm{~km}^{2}$. This increase was mainly due to the conversion of $26.31 \mathrm{~km}^{2}$ of cultivated land, $1.16 \mathrm{~km}^{2}$ of forest, $3.2 \mathrm{~km}^{2}$ shrub land, and $1.68 \mathrm{~km}^{2}$ of sandy areas into other areas, most of which were settlement areas. However, cultivated land declined by $37 \mathrm{~km}^{2}$ (from $6542 \mathrm{~km}^{2}$ to $6504 \mathrm{~km}^{2}$ ) during this period, which was mainly due to conversions to shrub land $\left(32.98 \mathrm{~km}^{2}\right)$, sandy areas $\left(17.96 \mathrm{~km}^{2}\right)$, forest $\left(8.30 \mathrm{~km}^{2}\right)$, and water bodies $\left(7.88 \mathrm{~km}^{2}\right)$.

Table 5. LULC transition from 1996 to 2006.

\begin{tabular}{|c|c|c|c|c|c|c|c|c|c|c|c|}
\hline Year & & & & & & 2006 & & & & & \\
\hline \multirow{11}{*}{1996} & LULC & UB & CL & FL & SL & BL & SA & WB & GL & SC & Total \\
\hline & OA & 182.33 & 0.52 & 00.00 & 00.00 & 0.01 & 0.33 & 0.04 & 0.00 & 00.00 & 183.24 \\
\hline & CL & 26.31 & 6448.64 & 8.30 & 32.98 & 0.03 & 17.96 & 7.88 & 0.41 & 0.00 & 6542.50 \\
\hline & FL & 1.16 & 7.65 & 9359.18 & 58.14 & 0.59 & 33.01 & 29.25 & 2.67 & 0.00 & 9491.65 \\
\hline & SL & 3.20 & 13.43 & 74.04 & 1125.23 & 0.30 & 27.99 & 0.64 & 3.93 & 0.00 & 1248.76 \\
\hline & BL & 0.55 & 0.07 & 0.46 & 2.73 & 256.57 & 1.90 & 0.35 & 27.29 & 1.16 & 291.07 \\
\hline & SA & 1.68 & 19.85 & 4.34 & 1.51 & 2.78 & 413.61 & 27.77 & 4.72 & 0.00 & 476.27 \\
\hline & WB & 0.85 & 13.05 & 0.29 & 0.63 & 1.08 & 25.10 & 231.29 & 0.71 & 0.00 & 272.99 \\
\hline & GL & 0.31 & 1.72 & 1.19 & 118.14 & 4.63 & 36.46 & 4.37 & 429.50 & 0.05 & 596.36 \\
\hline & SC & 00.00 & 00.00 & 00.00 & 0.09 & 68.10 & 00.00 & 0.36 & 2.77 & 82.38 & 153.70 \\
\hline & Total & 216.38 & 6504.93 & 9447.80 & 1339.45 & 334.08 & 556.36 & 301.96 & 471.99 & 83.59 & $19,256.54$ \\
\hline
\end{tabular}

Note: OA: Other area, CL: cultivated land, FL: forest land, SL: shrub land, BL: barren land, SA: sand area, WB: water bodies, GL: grass land, SC: snow and ice cover.

Similarly, despite the conversion of an $80 \mathrm{~km}^{2}$ area from other classes (e.g., $74 \mathrm{~km}^{2}$ from shrub land), forest cover witnessed an overall loss of $43 \mathrm{~km}^{2}\left(9491 \mathrm{~km}^{2}\right.$ to $9447 \mathrm{~km}^{2}$ ), with roughly $132 \mathrm{~km}^{2}$ forest being converted to other classes. In contrast, shrub land increased by $90 \mathrm{~km}^{2}$, mainly because of the conversion of $36 \mathrm{~km}^{2}$ of grassland areas into grassland areas. Sandy areas increased by $80 \mathrm{~km}^{2}$ (from $476 \mathrm{~km}^{2}$ to $556 \mathrm{~km}^{2}$ ) mostly due to the conversion from forest and grassland areas. Barren land mainly increased due to reductions in snow and ice cover (Table 5 and Figure 4).

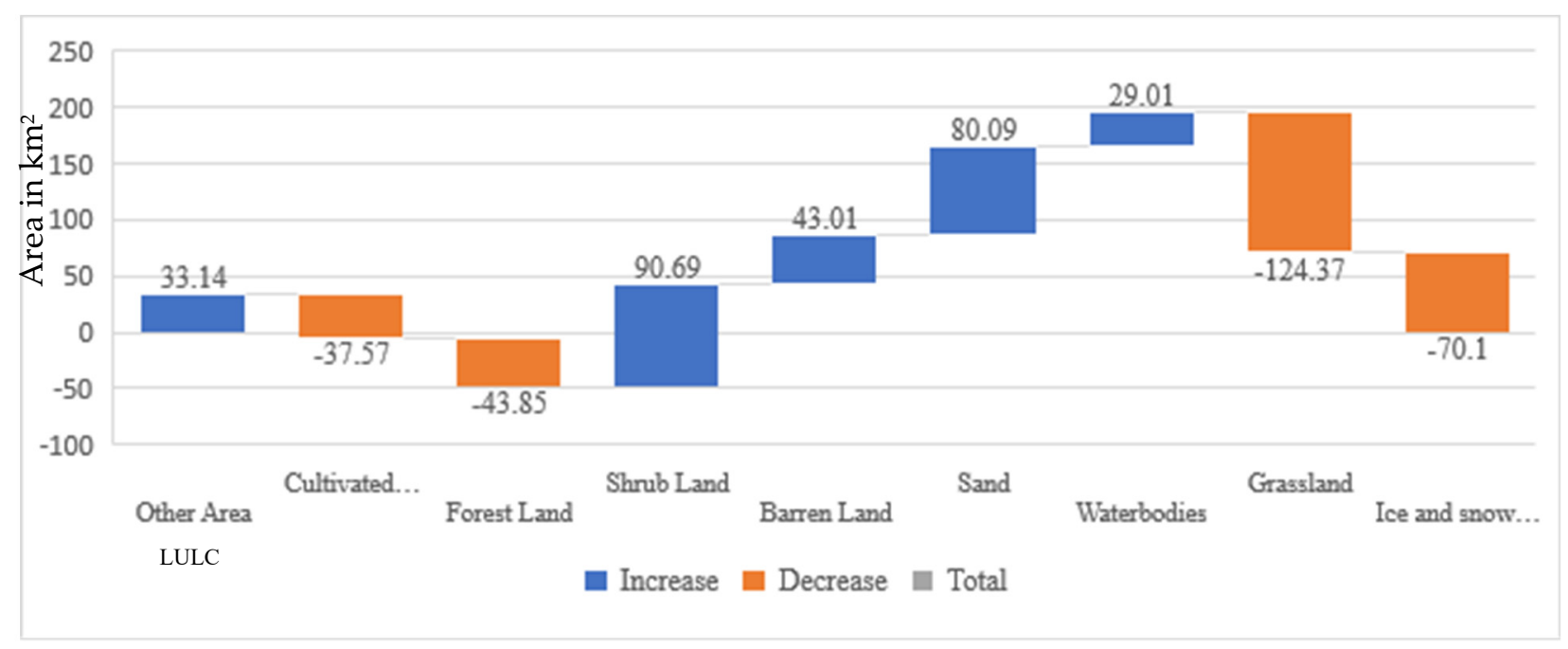

Figure 4. Gains and losses of LC classes between 1996 and 2006 (area in $\mathrm{km}^{2}$ ) based on the total LC values.

The major LC changes during this period include (a) overall increases in other areas in terms of settlement, barren land, forest, water body, and grass areas and (b) declines in cultivated land, shrub land, sandy areas, and ice/snow cover. Other areas with urban areas 
increased by $120.52 \mathrm{~km}^{2}$ (from $216.38 \mathrm{~km}^{2}$ to $336.9 \mathrm{~km}^{2}$ ), mainly due to the conversion of cultivated land $\left(97.44 \mathrm{~km}^{2}\right)$, forest $\left(9.45 \mathrm{~km}^{2}\right)$, sand areas $\left(5.86 \mathrm{~km}^{2}\right)$, and shrub land $\left(4.78 \mathrm{~km}^{2}\right)$.

Large portions of cultivated land were converted into other areas, particularly urban settlement areas, forests $\left(9.45 \mathrm{~km}^{2}\right)$, shrub land $\left(4.78 \mathrm{~km}^{2}\right)$, barren land $\left(1.67 \mathrm{~km}^{2}\right)$, and sand $\left(5.86 \mathrm{~km}^{2}\right)$, collectively resulting in the decline of cultivated land by $78.02 \mathrm{~km}^{2}$ (from $6504.93 \mathrm{~km}^{2}$ to $6426.91 \mathrm{~km}^{2}$ ). Overall, forest cover increased by $244 \mathrm{~km}^{2}$ (from $9447.8 \mathrm{~km}^{2}$ to $\left.9691.45 \mathrm{~km}^{2}\right)$, as large areas of shrub land $\left(317.36 \mathrm{~km}^{2}\right)$, sand $\left(44.02 \mathrm{~km}^{2}\right)$, and grassland $\left(27.35 \mathrm{~km}^{2}\right)$ transformed into forest cover. Shrub land reduced from $1339.45 \mathrm{~km}^{2}$ to $958.28 \mathrm{~km}^{2}$ due to its conversion to grassland $\left(123.3 \mathrm{~km}^{2}\right)$, forest $\left(317.36 \mathrm{~km}^{2}\right)$, cultivated land $\left(28.08 \mathrm{~km}^{2}\right)$, and other LC classes.

Similarly, $40 \mathrm{~km}^{2}$ of water body areas were converted to sand areas, and $37 \mathrm{~km}^{2}$ of sand areas were converted into water bodies. Based on this transition (Table 6), there were $9 \mathrm{~km}^{2}$ increases in water body areas and an $80 \mathrm{~km}^{2}$ sand area decrease. Around $31 \mathrm{~km}^{2}$ of snow- and ice-covered areas in the Himalayan region was converted from barren land alone; however, barren land still increased from a $334 \mathrm{~km}^{2}$ to a $350 \mathrm{~km}^{2}$ area. The majority of the grassland areas that were acquired were gained from cultivated land, forest land, shrub area, barren land, and sand and snow and ice cover areas, and grassland areas increased by $181 \mathrm{~km}^{2}\left(471 \mathrm{~km}^{2}\right.$ to $\left.652 \mathrm{~km}^{2}\right)$ (Table 6 and Figure 5).

Table 6. LC transition from 2006 to 2016.

\begin{tabular}{|c|c|c|c|c|c|c|c|c|c|c|c|}
\hline Year & & & & & & 2016 & & & & & \\
\hline \multirow{11}{*}{2006} & LULC & UB & CL & FL & SL & BL & SA & WB & GL & SC & Total \\
\hline & OA & 215.67 & 0.10 & 00.00 & 00.00 & 0.01 & 0.50 & 0.10 & 00.00 & 00.00 & 216.38 \\
\hline & CL & 97.44 & 6275.04 & 11.69 & 39.25 & 12.47 & 12.12 & 17.88 & 39.04 & 0.00 & 6504.93 \\
\hline & FL & 9.45 & 69.85 & 9281.43 & 44.61 & 0.68 & 4.49 & 7.26 & 30.04 & 0.00 & 9447.80 \\
\hline & SL & 4.78 & 28.08 & 317.36 & 849.33 & 5.41 & 4.38 & 6.72 & 123.30 & 0.10 & 1339.45 \\
\hline & BL & 1.67 & 1.21 & 0.72 & 10.52 & 282.62 & 6.60 & 0.84 & 22.12 & 7.78 & 334.08 \\
\hline & SA & 5.86 & 36.20 & 44.02 & 9.28 & 1.06 & 405.14 & 37.23 & 16.55 & 1.02 & 556.36 \\
\hline & WB & 1.28 & 9.83 & 8.88 & 0.38 & 0.13 & 40.40 & 238.75 & 2.30 & 0.00 & 301.95 \\
\hline & GL & 0.76 & 6.61 & 27.35 & 4.91 & 16.62 & 3.10 & 1.20 & 411.44 & 00.00 & 471.99 \\
\hline & SC & 00.00 & 00.00 & 00.00 & 00.00 & 31.27 & 0.04 & 0.02 & 7.28 & 45.11 & 83.72 \\
\hline & Total & 336.90 & 6426.91 & 9691.45 & 958.28 & 350.26 & 476.78 & 310.00 & 652.06 & 54.01 & $19,256.66$ \\
\hline
\end{tabular}

Note: OA: Other Areas: CL: cultivated land, FL: forest land, SL: shrub land, BL: barren land, SA: sand area, WB: water bodies, GL: grass land, SC: snow and ice cover.

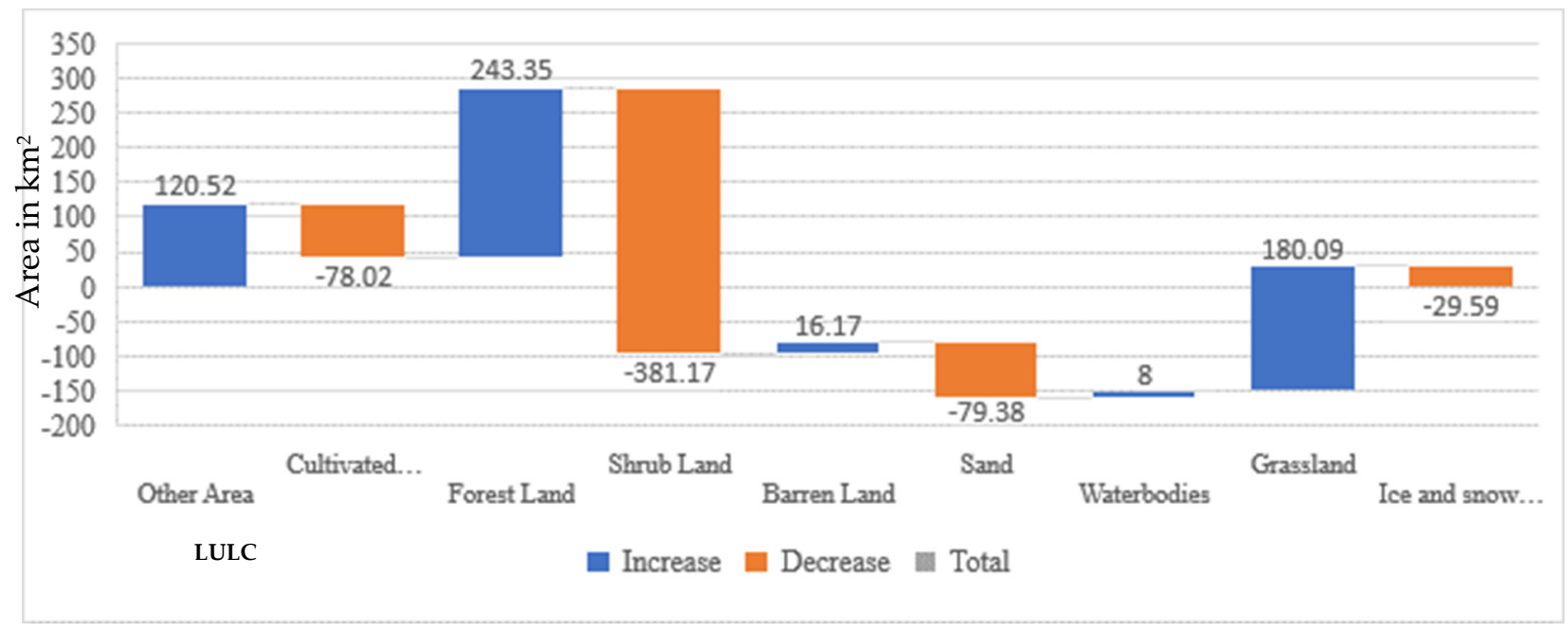

Figure 5. Gains and losses of LC classes between 2006 and 2016 (area in $\mathrm{km}^{2}$ ) based on the total LC values. 


\subsection{CA-Markov Model}

\subsubsection{Analysis of Transition Matrix}

For the analysis and prediction of the LC data, we computed a transition potential matrix based on LC conditions for the period of 1996, 2006, and 2016 to identify how each LC class was projected to change in the years 2026 and 2036. During the simulation, several LCs were converted into each other while some remained almost constant over time. The transition probability matrix predicted that cultivated land will be converted into other (urban/built-up) areas and that shrub land will be converted into forest. This probability matrix showed the transition of each LC class (Appendix A Table A1).

\subsubsection{Analysis of the Simulation Results}

Major changes predicted for 2016-2036 include increases in other areas, including settlement, forest, and water bodies; declines in shrub land, barren land, and cultivated land; and fluctuations for sand and grassland. According to the actual LC statistics and simulations, urban areas are predicted to increase from $1.75 \%$ in 2016 to $2.58 \%$ by 2026 and to $3.08 \%$ by 2036 (Table 7, Figures 6 and 7). In contrast, cultivated land will decrease from $33.38 \%$ in 2016 to $32.01 \%$ by 2026 and to $31.63 \%$ by 2036 . The simulations also suggest that forests will continue to increase and will increase from $50.33 \%$ in 2016 and to $50.74 \%$ and $51.76 \%$ by 2026 and 2036, respectively. However, shrub area will continue to decrease in 2026 and 2036, mainly because of its conversion to forests. Similarly, cultivated land will also continue to be converted into forests.

Table 7. LULC change of the study area during 2016-2036 (in $\mathrm{km}^{2}$ and percent).

\begin{tabular}{|c|c|c|c|c|c|c|}
\hline LULC & 2016 & 2026 & 2036 & $\begin{array}{l}\text { Change } \\
2016-2026\end{array}$ & $\begin{array}{l}\text { Change } \\
2016-2036\end{array}$ & $\begin{array}{c}\text { Change } \\
2026-2036\end{array}$ \\
\hline \multirow{2}{*}{ Other area } & 336.9 & 496.46 & 593.79 & 159.56 & 256.89 & 97.33 \\
\hline & $1.75 \%$ & $2.58 \%$ & $3.08 \%$ & $47.36 \%$ & $76.25 \%$ & $19.6 \%$ \\
\hline \multirow{2}{*}{ Cultivated Land } & 6426.91 & 6164.51 & 6089.78 & -262.4 & -337.13 & -74.73 \\
\hline & $33.38 \%$ & $32.01 \%$ & $31.63 \%$ & $-4.08 \%$ & $-5.24 \%$ & $-1.21 \%$ \\
\hline \multirow{2}{*}{ Forest Land } & 9691.15 & 9771.05 & 9966.29 & 79.9 & 275.14 & 195.24 \\
\hline & $50.33 \%$ & $50.74 \%$ & $51.76 \%$ & $0.82 \%$ & $2.84 \%$ & $1.99 \%$ \\
\hline \multirow{2}{*}{ Shrub land } & 958.28 & 913.85 & 815.21 & -44.43 & -143.07 & -98.64 \\
\hline & $4.98 \%$ & $4.75 \%$ & $4.23 \%$ & $-4.64 \%$ & $-14.92 \%$ & -10.79 \\
\hline \multirow{2}{*}{ Barren Land } & 350.25 & 338.61 & 320.05 & -11.64 & -30.2 & -18.56 \\
\hline & $1.82 \%$ & $1.76 \%$ & $1.66 \%$ & $-3.32 \%$ & -8.62 & -5.48 \\
\hline \multirow{2}{*}{ Sand } & 476.98 & 554.65 & 422.91 & 77.67 & -54.07 & -131.74 \\
\hline & $2.48 \%$ & $2.88 \%$ & $2.20 \%$ & $16.28 \%$ & $-11.33 \%$ & -23.75 \\
\hline \multirow{2}{*}{ Water Body } & 310 & 323.39 & 359.71 & 13.39 & 49.71 & 36.32 \\
\hline & $1.61 \%$ & $1.68 \%$ & $1.87 \%$ & $4.32 \%$ & $16.03 \%$ & $11.23 \%$ \\
\hline \multirow{2}{*}{ Grassland } & 652.08 & 639.94 & 645.74 & -12.14 & -6.34 & 5.8 \\
\hline & $3.39 \%$ & $3.32 \%$ & $3.35 \%$ & $-1.86 \%$ & $-0.97 \%$ & $0.9 \%$ \\
\hline \multirow{2}{*}{ Ice and Snow Cover } & 54.01 & 53.55 & 42.51 & -0.46 & -11.5 & -11.04 \\
\hline & $0.28 \%$ & $0.28 \%$ & $0.22 \%$ & $-0.85 \%$ & $-21.29 \%$ & -20.62 \\
\hline
\end{tabular}




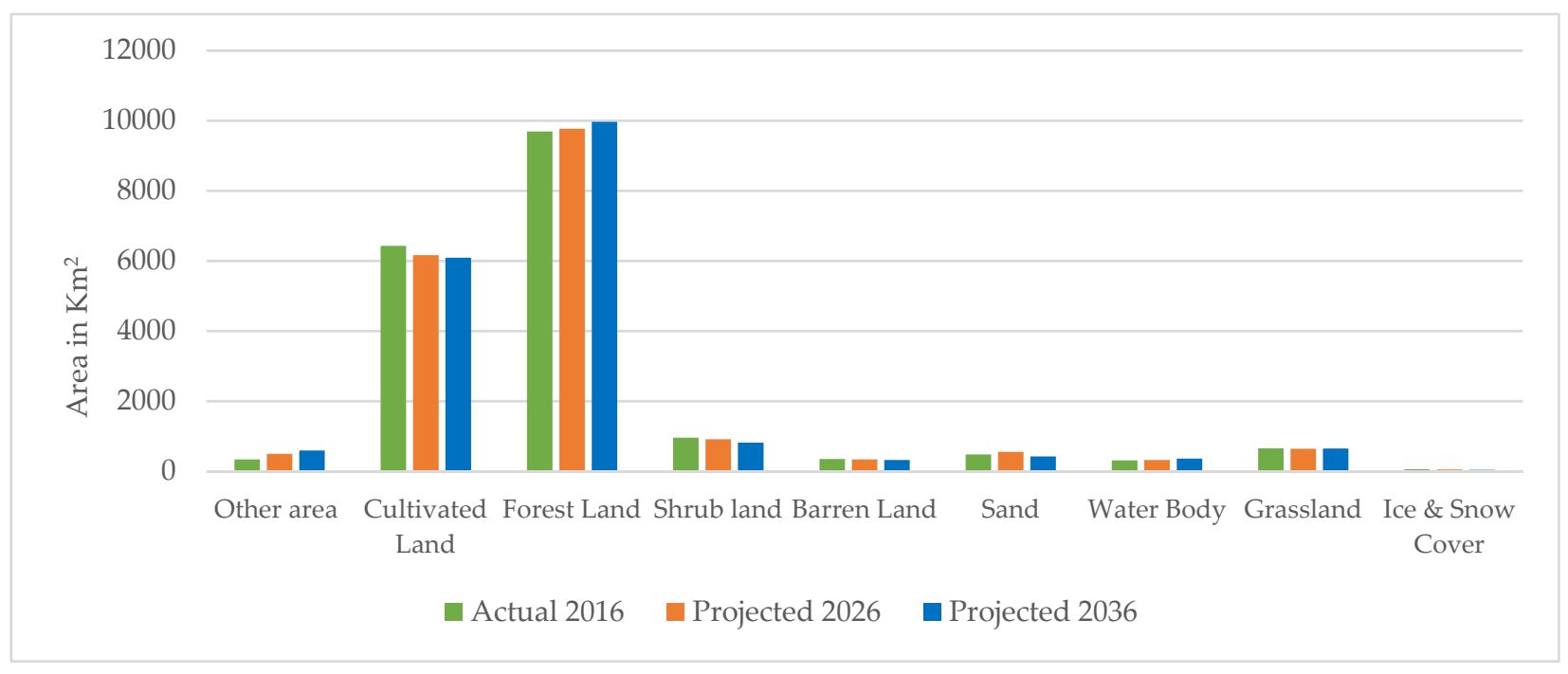

Figure 6. Trend of LULC changes in the study area from 2016 to 2036.
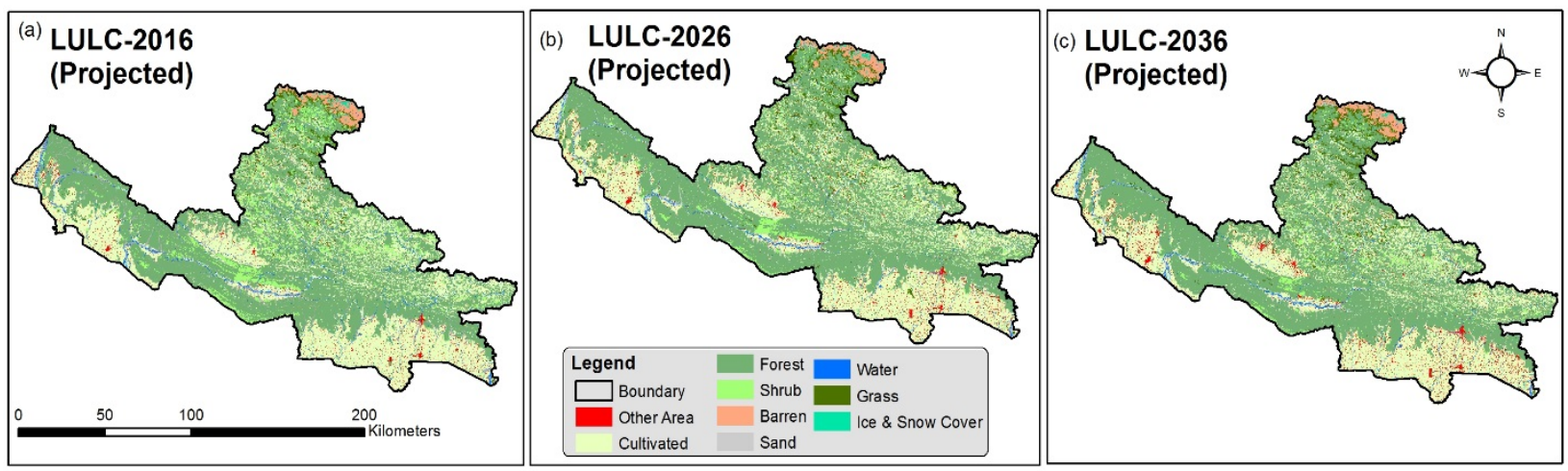

Figure 7. LC-Projected map of Lumbini Province: (a) 2016; (b) 2026; (c) 2036.

\section{Discussion}

Our results show that overall forest cover increased during the period of 1996-2016. Community-based forest management and other programs were responsible for the overall increase in forest cover in the study area. Similarly, the National Biodiversity Strategy and Action Plan provided a strategic roadmap for biodiversity conservation in Nepal [97]. As a result, by 2018, the country had a total of 12 National Parks, 1 wildlife reserve, 1 hunting reserve, 6 conservation areas, and 13 buffer zones, accounting for $23.39 \%\left(34,419 \mathrm{~km}^{2}\right)$ of the total land area (http://www.dnpwc.gov.np/en/, accessed on 30 August 2021). Additionally, different local and international level donor agencies such as IUCN, UNDP, WWF, and ICIMOD [98] supported environmental management and forest conservation. This increased forest cover has enhanced the conservation of endangered species and has enhanced animal biodiversity [99].

Forest area increases were mainly due to greater community level conservation practices and forest management strategies [22]. Further, urban area increases due to population growth resulted in migration from the highlands to the lowlands [55], causing abandoned cultivated land in upstream areas, which have turned into vegetation cover, leading to increases in forest cover [100,101]. Political conflict between 1996 and 2006 caused many people to migrate to more secure urban areas from agricultural areas in the mid-hills, resulting in the abandonment of agricultural lands and increased forest cover [102]. However, forest encroachment was higher in the Tarai region over the same period. Erosion, lowland flooding, urbanization, and deforestation are major causes of forest degradation in the lowlands (Tarai) of Nepal. The forest cover in Tarai was found to decrease between 2001 
and 2010, and major losses occurred in the Kapilbastu district [103]. Similarly, our results also showed an overall decline in forest cover during the period from 1996 to 2006.

About 38\% of people in Asia use wood fuel [2], and 70\% of the total energy that is produced by people in rural Nepal is from firewood [104]. However, the consumption of fuel wood for cooking has reduced by 3.3 times over the last decade and has been replaced by the use of liquefied petroleum gas [105]. Community forest programs provide strong support for energy management and carbon storage [20]. Nepal's decade of forestry (2014-2024) aims to conserve forest resources and to create urban greenery in cities and towns throughout the country. Operational plans for community-managed forest programs emphasize the control of forest fires [106], encroachment and illegal logging, forest awareness campaigns and monitoring, and silvicultural practices for the sustainable utilization of forest resources [107]. As a result, such programs should play an important role in mitigating greenhouse gases and reducing the impacts of climate change as well as preserving forest biodiversity.

Local-level plans and strategies also provide support for the future restoration of forests. The Tilottama municipality located in the Rupandehi district (Appendix B Figure A1: Map 1), for example, has introduced a plantation (about 0.3 million plants) program that will cover the period of 2017-2022. Butwal sub-metropolitan city has a similar program for the Tinau corridor and other areas, and the Sainamaina municipality has identified forest zones where they are promoting forest development on barren land. In total, 20 local governments have plantation programs in this region. These include roadside plantations, trees and green spaces in urban areas, the "one house two plantations program", riparian plantation programs, barren land plantations, and the promotion of agroforestry and private forests [108].

The Nepalese government is promoting agroforestry in the region and has put a forestry decade into place (2014-2024) with the motto of "one house one tree". Many of the suggested changes are in keeping with landscape and watershed level plans to adapt to climate change as set out in the 2010 National Adaptation Programme of Action (NAPA) and the 2011 Local Adaptation Plan of Action (LAPA). Plans at the national level emphasize forest preservation, the control of forest fires and invasive species, community-based integrated forest management, wetland and riverine forest conservation, and agroforestry. The action plan identifies local adaptations that are needed to mitigate climate change vulnerabilities while boosting resilience [109]. The trade agreement between the Nepalese government and the World Bank's Forest Carbon Partnership Facilities (FCPF) also encourage forest conservation in Nepal. Agroforestry practices (combined agriculture practices with forest and fruits) also support the maintenance of a green environment.

Community forestry has been successful in improving forest stocks, with increases in canopy cover [18], tree species diversity [110], growing stock, and biodiversity [111] being observed, all of which are due to reduced human pressure on forests [110]. Similar trends have been observed in provincial-level studies in Province One and in the Gandaki Province in Nepal $[79,112]$. Several studies have shown that forest cover of Nepal has increased in different regions. Tuladhar et al., 2019, explored forest cover changes in the entire catchment areas of the Bagmati river basin and found that forest cover increased by $4.1 \%$ between 1975 and 2005 in the middle section and overall for the basin. However, the forest change ratio differs in the upper and downstream sections of the catchment area [44]. Similarly, the overall forest cover area increased in the Phewa watershed during the periods of 1995-2017 [113] and 1975-2015 [114] and in the Tanahun district during the period of 1976-2015 [41]. At the national level, the annual deforestation rate decreased from $1.31 \%$ during the period of $1930-1975$ to $0.01 \%$ in $2005-2014$, and forest patch areas increased from $6925 \mathrm{~km}^{2}$ in 1930 to $42,961 \mathrm{~km}^{2}$ in 2014 [21], whereas national forest cover increased from $38 \%$ in $1978-1979$ to $40.36 \%$ by 2015 [20]. A similar trend was observed in our study, where forested areas increased between 2006 and 2016. 


\section{Conclusions}

Our analysis revealed that during 1996-2016, the study area witnessed declines in cultivated land, shrub land, sand areas, and ice/snow cover and increases in other LC, including urban areas, forest cover, barren land, water bodies, and grassland. Meanwhile, our predictions suggest that other areas, forested areas, and water bodies will continue to increase and that shrub land, barren land, and cultivated land will decline during the period of 2016-2036. We analyzed national forest management practices and policies and found multiple factors that were associated with historical and future trends of forest cover change. Community forest management practices, watershed management strategies, and forest carbon partnership facilities (FCPF) also encourage forest conservation at the local level. However, settlement expansion, forest encroachment, illegal logging, and forest fires are major challenges for the Tarai region (southern plains). As such, effective forest planning, particularly urban forest management, is essential for sustaining environmental equilibrium in the future. For this to occur, it is essential that forest protection and restoration plans and programs are formulated and are implemented at the national, provincial, and local levels in order to maintain the minimum amount of forested area.

We recognize a number of limitations of our study. We applied medium-resolution satellite imagery due challenges in capturing real-time high-resolution data [101]. Further, we only identified nine major LC classes. Accurate assessment of planted forests was difficult due to the low resolution of the available satellite images. Other uncertainties are related to natural factors, which include complex topography and seasonal snow- and ice-covered areas where ground truthing was not possible. We evaluated the LC changes at the provincial level, and we did not attempt to identify individual forest types or species, which we will consider in the future. Hence, we recommend the use of high-resolution satellite images for the finer evaluation of LC classes with forest species changes in the future. Existing policies should prioritize different forest species and tree-based ecosystem service-oriented management goals [115] in different geographical regions (mountain, hill, and Tarai). These will help maximize the benefits to local people and will help to maintain sustainable forest management in different ecological zones. Similarly, decision makers and scientists will need to apply suitable quantitative tools such as machine learning techniques and artificial intelligent (AI) methods for further data analysis and for the forecasting of environmental change.

Author Contributions: Conceptualization, B.R.; methodology, B.R.; software, B.R.; validation, B.R., H.K. and S.R.; formal analysis, B.R.; investigation, B.R.; resources, B.R.; writing-original draft preparation, B.R., H.K. and S.R.; writing-review and editing, B.R., H.K., N.S. and S.R.; visualization, B.R.; supervision, B.R.; project administration, B.R.; funding acquisition, B.R. All authors have read and agreed to the published version of the manuscript.

Funding: This research work received no external funding.

Data Availability Statement: Landsat TM, ETM and OLI Images of the study area were collected for the years 1996, 2006, and 2016 from the USGS website (earthexplorer.usgs.gov, accessed on 30 August 2021) and land cover data were prepared. The land cover data presented in the study are not publicly available.

Acknowledgments: The authors would like to thank all of the scientists who supported use during the field work.

Conflicts of Interest: The authors declare no conflict of interest. 


\section{Appendix A}

Table A1. Transition probability matrix calculated using land-cover maps of 1996-2006, 2006-2016, and 1996-2016.

\begin{tabular}{|c|c|c|c|c|c|c|c|c|c|c|}
\hline & LULC. & Other Area. & Cultivated. & Forest. & Shrub. & Barren. & Sand. & Water. & Grass. & Ice \& Snow. \\
\hline \multirow{9}{*}{ 1996-2006 } & Other area. & 0.9357 & 0.0122 & 0.0424 & 0.0007 & 0.0002 & 0.0078 & 0.0010 & 0.0000 & 0.0000 \\
\hline & Cultivated & 0.0189 & 0.9364 & 0.0044 & 0.0224 & 0.0000 & 0.0122 & 0.0054 & 0.0003 & 0.0000 \\
\hline & Forest & 0.0005 & 0.0035 & 0.9368 & 0.0279 & 0.0003 & 0.0157 & 0.0140 & 0.0013 & 0.0000 \\
\hline & Shrub & 0.0037 & 0.0156 & 0.0863 & 0.8561 & 0.0003 & 0.0326 & 0.0008 & 0.0046 & 0.0000 \\
\hline & Barren & 0.0026 & 0.0003 & 0.0018 & 0.0129 & 0.8377 & 0.0090 & 0.0016 & 0.1287 & 0.0055 \\
\hline & Sand & 0.0046 & 0.0555 & 0.0120 & 0.0042 & 0.0078 & 0.8260 & 0.0778 & 0.0121 & 0.0000 \\
\hline & Water & 0.0040 & 0.0610 & 0.0012 & 0.0029 & 0.0050 & 0.1175 & 0.8050 & 0.0033 & 0.0000 \\
\hline & Grass & 0.0006 & 0.0032 & 0.0020 & 0.2237 & 0.0088 & 0.0690 & 0.0083 & 0.6844 & 0.0001 \\
\hline & Ice \& Snow & 0.0000 & 0.0000 & 0.0000 & 0.0001 & 0.3183 & 0.0020 & 0.0013 & 0.0191 & 0.6593 \\
\hline \multirow{9}{*}{ 2006-2016 } & Other area & 0.9500 & 0.0063 & 0.0063 & 0.0063 & 0.0063 & 0.0063 & 0.0063 & 0.0063 & 0.0063 \\
\hline & Cultivated & 0.0383 & 0.9202 & 0.0038 & 0.0154 & 0.0006 & 0.0028 & 0.0070 & 0.0118 & 0.0000 \\
\hline & Forest & 0.0036 & 0.0281 & 0.9333 & 0.0179 & 0.0003 & 0.0018 & 0.0029 & 0.0121 & 0.0000 \\
\hline & Shrub & 0.0039 & 0.0228 & 0.1575 & 0.7025 & 0.0044 & 0.0036 & 0.0053 & 0.1000 & 0.0001 \\
\hline & Barren & 0.0064 & 0.0046 & 0.0028 & 0.0402 & 0.8041 & 0.0252 & 0.0032 & 0.0876 & 0.0259 \\
\hline & Sand & 0.0120 & 0.0743 & 0.0903 & 0.0190 & 0.0022 & 0.7215 & 0.0562 & 0.0242 & 0.0004 \\
\hline & Water & 0.0051 & 0.0388 & 0.0350 & 0.0015 & 0.0005 & 0.1593 & 0.7518 & 0.0081 & 0.0000 \\
\hline & Grass & 0.0022 & 0.0188 & 0.0777 & 0.0140 & 0.0472 & 0.0088 & 0.0034 & 0.8280 & 0.0000 \\
\hline & Ice \& Snow & 0.0000 & 0.0000 & 0.0000 & 0.0000 & 0.1960 & 0.0006 & 0.0003 & 0.0922 & 0.7110 \\
\hline \multirow{9}{*}{ 1996-2016 } & Other area & 0.9459 & 0.0165 & 0.0151 & 0.0040 & 0.0001 & 0.0081 & 0.0102 & 0.0000 & 0.0000 \\
\hline & Cultivated & 0.0443 & 0.9149 & 0.0039 & 0.0161 & 0.0005 & 0.0045 & 0.0053 & 0.0104 & 0.0000 \\
\hline & Forest & 0.0034 & 0.0245 & 0.9307 & 0.0188 & 0.0004 & 0.0018 & 0.0102 & 0.0102 & 0.0000 \\
\hline & Shrub & 0.0077 & 0.0187 & 0.1942 & 0.7278 & 0.0043 & 0.0211 & 0.0062 & 0.0198 & 0.0001 \\
\hline & Barren & 0.0091 & 0.0050 & 0.0032 & 0.0456 & 0.7460 & 0.0290 & 0.0040 & 0.1503 & 0.0077 \\
\hline & Sand & 0.0120 & 0.0497 & 0.0429 & 0.0069 & 0.0072 & 0.7580 & 0.1004 & 0.0226 & 0.0002 \\
\hline & Water & 0.0089 & 0.0540 & 0.0068 & 0.0034 & 0.0034 & 0.1878 & 0.7246 & 0.0111 & 0.0000 \\
\hline & Grass & 0.0029 & 0.0154 & 0.0533 & 0.0425 & 0.0179 & 0.0601 & 0.0161 & 0.7918 & 0.0000 \\
\hline & Ice \& Snow & 0.0000 & 0.0000 & 0.0000 & 0.0000 & 0.2789 & 0.0031 & 0.0017 & 0.0795 & 0.6368 \\
\hline
\end{tabular}




\section{Appendix B}

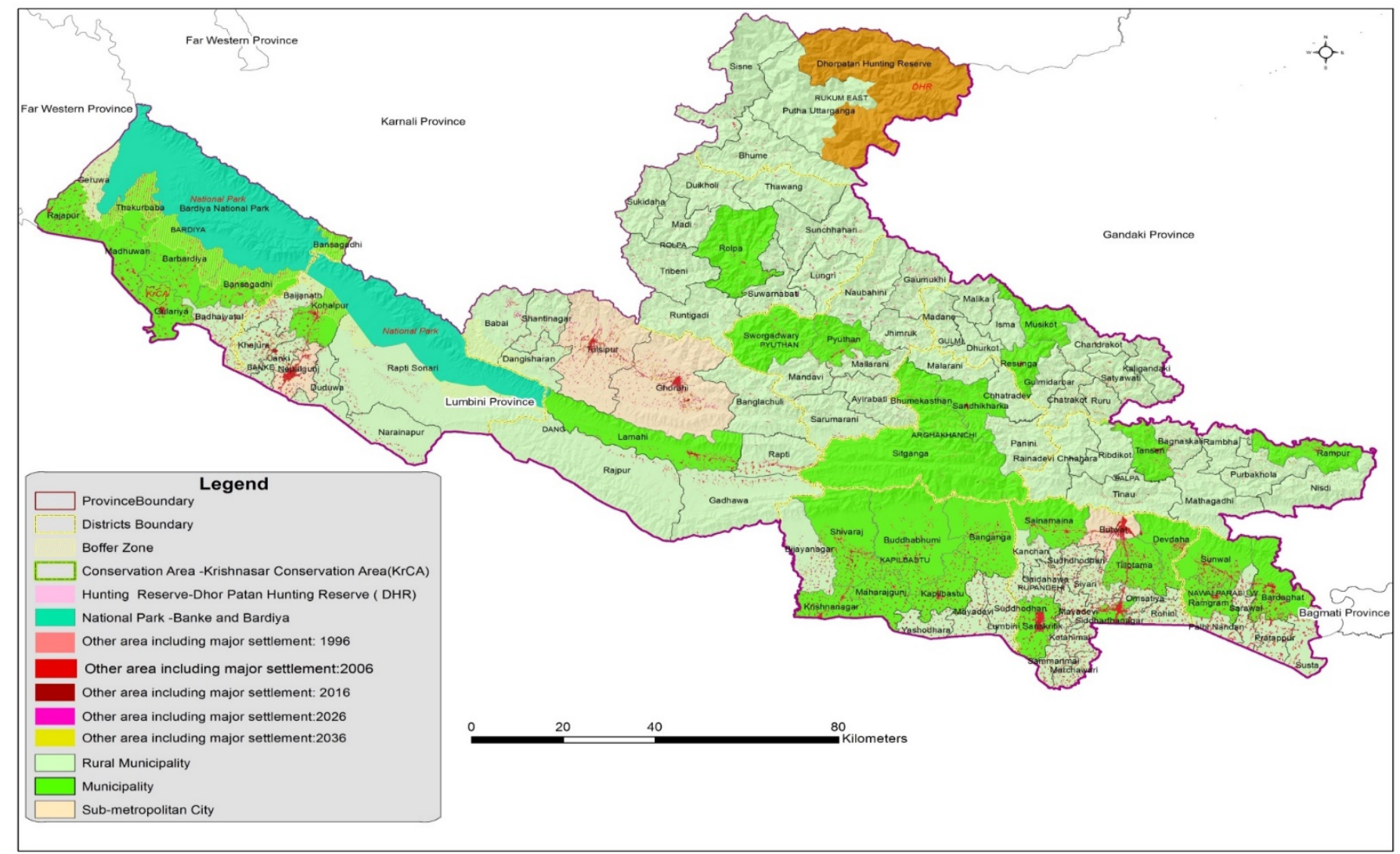

Figure A1. Map 1: Protected area, Sub-Metropolitan City, Municipality and Rural Municipality of Lumbini Province.

\section{References}

1. de Jong, W.; Galloway, G.; Pierce Colfer, C.J.; Katila, P.; Winkel, G.; Pacheco, P. Synergies, Trade-Offs and Contextual Conditions Shaping Impacts of the Sustainable Development Goals on Forests and People. In Sustainable Development Goals: Their Impacts on Forests and People; Pierce Colfer, C.J., Winkel, G., Galloway, G., Pacheco, P., Katila, P., de Jong, W., Eds.; Cambridge University Press: Cambridge, UK, 2019; pp. 577-600.

2. FAO. The State of the World's Forests 2018-Forest Pathways to Sustainable Development; Food and Agriculture Organization: Rome, Italy, 2018.

3. UNDESA. The Global Forest Goals Report 2021, Realizing the Importance of Forests in A Changing World; United Nation Department of Economic and Social Affairs: New York, NY, USA, 2021.

4. Löf, M.; Madsen, P.; Metslaid, M.; Witzell, J.; Jacobs, D.F. Restoring forests: Regeneration and ecosystem function for the future. New For. 2019, 50, 139-151. [CrossRef]

5. Noulèkoun, F.; Mensah, S.; Birhane, E.; Son, Y.; Khamzina, A. Forest Landscape Restoration under Global Environmental Change: Challenges and a Future Roadmap. Forests 2021, 12, 276. [CrossRef]

6. UN. The 2030 Agenda for Sustainable Development- SDGs 15; United Nations: New York, NY, USA, 2015.

7. UN. Transforming Our World: The 2030 Agenda for Sustainable Development; United Nations: New York, NY, USA, 2015.

8. Dave, R.; Saint-Laurent, C.; Murray, L.; Antunes Daldegan, G.; Brouwer, R.; de Mattos Scaramuzza, C.A.; Raes, L.; Simonit, S.; Catapan, M.; García Contreras, G.; et al. Second Bonn Challenge Progress Report. Application of the Barometer in 2018; IUCN: Gland, Switzerland, 2019.

9. UN. United Nations General Assembly, United Nations Decade on Ecosystem Restoration 2021-2030; United Nations: New York, NY, USA, 2019.

10. FAO. Global Forest Resources Assessment 2020, Key Findings; Food and Agriculture Organization: Rome, Italy, 2020. [CrossRef]

11. Borah, B.; Bhattacharjee, A.; Ishwar, N. Bonn Challenge and India: Progress on Restoration Efforts across States and Landscapes; IUCN: Gland, Switzerland, 2018.

12. Choi, G.; Jeong, Y.; Kim, S.-I. Success Factors of National-Scale Forest Restorations in South Korea, Vietnam, and China. Sustainability 2019, 11, 3488. [CrossRef]

13. Van Oosten, C.; Gunarso, P.; Koesoetjahjo, I.; Wiersum, F. Governing Forest Landscape Restoration: Cases from Indonesia. Forests 2014, 5, 1143-1162. [CrossRef] 
14. Feng, X.; Fu, B.; Lu, N.; Zeng, Y.; Wu, B. How ecological restoration alters ecosystem services: An analysis of carbon sequestration in China's Loess Plateau. Sci. Rep. 2013, 3, 2846. [CrossRef] [PubMed]

15. Djenontin, I.N.S.; Zulu, L.C.; Etongo, D. Ultimately, what is Forest Landscape Restoration in Practice? Embodiments in SubSaharan Africa and Implications for Future Design. Environ. Manag. 2020, 1-23. [CrossRef] [PubMed]

16. De Jong, W.; Liu, J.; Long, H. The forest restoration frontier. Ambio 2021, 1-14. [CrossRef]

17. Oosthoek, K.J.; Hölzl, R. (Eds.) Managing Northern Europe's Forests, Histories from the Age of Improvement to the Age of Ecology, 1st ed.; Berghahn Books: New York, NY, USA, 2018; Volume 12, pp. i-iv.

18. Oli, B.N.; Shrestha, K. Carbon status in forests of Nepal: An overview. For. Trees Livelihoods 2009, 8, 62-66.

19. FAO. Global Forest Resources Assessment Country Reports, Nepal; Forestry Department Food and Agriculture Organization of the United Nations: Rome, Italy, 2005.

20. DFRS. State of Nepal's Forests; DFRS: Kathmandu, Nepal, 2015.

21. Sudhakar Reddy, C.; Vazeed Pasha, S.; Satish, K.V.; Saranya, K.R.L.; Jha, C.S.; Krishna Murthy, Y.V.N. Quantifying nationwide land cover and historical changes in forests of Nepal (1930-2014): Implications on forest fragmentation. Biodivers. Conserv. 2018, 27, 91-107. [CrossRef]

22. MSFP. Scientific Forest Management Initiatives in Nepal; Multi-Stakeholder Forestry Program, Government of Nepal, Singhadurbar: Kathmandu, Nepal, 2016.

23. Agrawal, A.; Chhatre, A. Explaining success on the commons: Community forest governance in the Indian Himalaya. World Dev. 2006, 34, 149-166. [CrossRef]

24. Niraula, R.R.; Gilani, H.; Pokharel, B.K.; Qamer, F.M. Measuring impacts of community forestry program through repeat photography and satellite remote sensing in the Dolakha district of Nepal. J. Environ. Manag. 2013, 126, 20-29. [CrossRef]

25. Kanel, K.R.; Niraula, D.R. Can rural livelihood be improved in Nepal, through community forestry? Banko Janakari 2004, 14, 19-26. [CrossRef]

26. GoN. Forest Act 1993; Government of Nepal (His Majesty's): Kathmandu, Nepal, 1993.

27. GoN. Forest Regulation 1995; Government of Nepal (His Majesty's): Kathmandu, Nepal, 1995.

28. Paudel, N.; Adhikary, A.; Mbairamadji, J.; Nguyen, T. Small-Scale Forest Enterprise Development in Nepal: Overview, Issues and Challenges; FAO: Rome, Italy, 2018.

29. Rizvi, A.R.; Baig, S.; Barrow, E.; Kumar, C. Synergies between Climate Mitigation and Adaptation in Forest Landscape Restoration; IUCN: Gland, Switzerland, 2015.

30. Jacobs, D.F.; Oliet, J.A.; Aronson, J.; Bolte, A.; Bullock, J.M.; Donoso, P.J.; Landhäusser, S.M.; Madsen, P.; Peng, S.; Rey-Benayas, J.M.; et al. Restoring forests: What constitutes success in the twenty-first century? New For. 2015, 46, 601-614. [CrossRef]

31. Milder, J.C.; Scherr, S.J.; Bracer, C. Trends and future potential of payment for ecosystem services to alleviate rural poverty in developing countries. Ecol. Soc. 2010, 15, 4. [CrossRef]

32. World Bank. Nepal Emission Reductions Program in the Terai Arc Landscape (p165375), Report no: 156033-np; World Bank: Washington, DC, USA, 2021.

33. GoN. Constitution of Nepal, 2015; Government of Nepal, Singha Durbar: Kathmandu, Nepal, 2015.

34. Chaudhary, R.; Uprety, Y.; Rimal, S. Deforestation in Nepal; Elsevier: Amsterdam, The Netherlands, 2016 ; pp. 335-372.

35. World Bank. Valuing Green Infrastructure, Case Study of Kali Gandaki Watershed, Nepal; World Bank: Washington, DC, USA, 2017.

36. Kharal, D.K.; Ddhungana, M. Forest Coverage and Biodiversity in Nepal; Dhakal, M., Lamichhane, D., Ghimire, M.D., Poudyal, A., Uprety, Y., Svich, T., Pandey, M., Eds.; Ministry of Forest and Environment (MoFE), Singhadurbar: Kathmandu, Nepal, 2018.

37. Oli, B.N.; Dhakal, M. Policy and Institutional Reform to Biodiversity Conservation in Nepal; Dhakal, M., Lamichhane, D., Ghimire, M.D., Poudyal, A., Uprety, Y., Svich, T., Pandey, M., Eds.; Ministry of Forest and Environment (MoFE), Singhadurbar: Kathmandu, Nepal, 2018.

38. Aryal, K.; Rijal, A.; Maraseni, T.; Parajuli, M. Why is the Private Forest Program Stunted in Nepal? Environ. Manag. 2020, 66, 535-548. [CrossRef] [PubMed]

39. Garrard, R.; Kohler, T.; Price, M.F.; Byers, A.C.; Sherpa, A.R.; Maharjan, G.R. Land Use and Land Cover Change in Sagarmatha National Park, a World Heritage Site in the Himalayas of Eastern Nepal. Mt. Res. Dev. 2016, 36, 299-310. [CrossRef]

40. Wang, S.W.; Gebru, B.M.; Lamchin, M.; Kayastha, R.B.; Lee, W.-K. Land Use and Land Cover Change Detection and Prediction in the Kathmandu District of Nepal Using Remote Sensing and GIS. Sustainability 2020, 12, 3925. [CrossRef]

41. Tripathi, S.; Subedi, R.; Adhikari, H. Forest Cover Change Pattern after the Intervention of Community Forestry Management System in the Mid-Hill of Nepal: A Case Study. Remote Sens. 2020, 12, 2756. [CrossRef]

42. Paudel, B.; Gao, J.; Zhang, Y.; Wu, X.; Li, S.; Yan, J. Changes in Cropland Status and Their Driving Factors in the Koshi River Basin of the Central Himalayas, Nepal. Sustainability 2016, 8, 933. [CrossRef]

43. Rijal, S.; Rimal, B.; Acharya, R.P.; Stork, N.E. Land use/land cover change and ecosystem services in the Bagmati River Basin, Nepal. Environ. Monit. Assess. 2021, 193, 1-17. [CrossRef]

44. Tuladhar, D.; Dewan, A.; Kuhn, M.; Corner, R.J. The Influence of Rainfall and Land Use/Land Cover Changes on River Discharge Variability in the Mountainous Catchment of the Bagmati River. Water 2019, 11, 2444. [CrossRef]

45. Rai, R.; Zhang, Y.; Paudel, B.; Acharya, B.K.; Basnet, L. Land Use and Land Cover Dynamics and Assessing the Ecosystem Service Values in the Trans-Boundary Gandaki River Basin, Central Himalayas. Sustainability 2018, 10, 3052. [CrossRef] 
46. Keshtkar, H.; Voigt, W. Potential impacts of climate and landscape fragmentation changes on plant distributions: Coupling multi-temporal satellite imagery with GIS-based cellular automata model. Ecol. Inform. 2016, 32, 145-155. [CrossRef]

47. Yohannes, H.; Soromessa, T.; Argaw, M.; Dewan, A. Spatio-temporal changes in habitat quality and linkage with landscape characteristics in the Beressa watershed, Blue Nile basin of Ethiopian highlands. J. Environ. Manag. 2021, 281, 111885. [CrossRef]

48. Oduro Appiah, J.; Agyemang-Duah, W.; Sobeng, A.K.; Kpienbaareh, D. Analysing patterns of forest cover change and related land uses in the Tano-Offin forest reserve in Ghana: Implications for forest policy and land management. Trees For. People 2021, 5, 100105. [CrossRef]

49. Lister, A.J.; Andersen, H.; Frescino, T.; Gatziolis, D.; Healey, S.; Heath, L.S.; Liknes, G.C.; McRoberts, R.; Moisen, G.G.; Nelson, M.; et al. Use of Remote Sensing Data to Improve the Efficiency of National Forest Inventories: A Case Study from the United States National Forest Inventory. Forests 2020, 11, 1364. [CrossRef]

50. Song, X.-P.; Hansen, M.C.; Stehman, S.V.; Potapov, P.V.; Tyukavina, A.; Vermote, E.F.; Townshend, J.R. Global land change from 1982 to 2016. Nature 2018, 560, 639-643. [CrossRef] [PubMed]

51. Dewan, A.M.; Kabir, M.H.; Nahar, K.; Rahman, M.Z. Urbanisation and environmental degradation in Dhaka Metropolitan Area of Bangladesh. Int. J. Environ. Sustain. Dev. 2012, 11, 118-147. [CrossRef]

52. Eastman, J.; Van Fossen, M.E.; Solo'rzano, L.A. Transition Potential Modeling for Land-Cover Change, 1st ed.; ESRI Press: New York, NY, USA, 2005.

53. Sloan, S.; Zamora Pereira, J.C.; Labbate, G.; Asner, G.P.; Imbach, P. The cost and distribution of forest conservation for national emissions reductions. Glob. Environ. Chang. 2018, 53, 39-51. [CrossRef]

54. Zhang, D.; Huang, Q.; He, C.; Yin, D.; Liu, Z. Planning urban landscape to maintain key ecosystem services in a rapidly urbanizing area: A scenario analysis in the beijing-tianjin-hebei urban agglomeration, China. Science 2018, 96, 559-571. [CrossRef]

55. Rijal, S.; Rimal, B.; Stork, N.; Sharma, H.P. Quantifying the drivers of urban expansion in Nepal. Environ. Monit. Assess. 2020, 192, 1-17. [CrossRef] [PubMed]

56. Watson, C.; Kargel, J.; Regmi, D.; Rupper, S.; Maurer, J.; Karki, A. Shrinkage of Nepal's Second Largest Lake (Phewa Tal) Due to Watershed Degradation and Increased Sediment Influx. Remote Sens. 2019, 11, 444. [CrossRef]

57. Seto, K.C.; Fragkias, M. Mangrove conversion and aquaculture development in Vietnam: A remote sensing-based approach for evaluating the Ramsar Convention on Wetlands. Glob. Environ. Chang. 2007, 17, 486-500. [CrossRef]

58. Rodrigues, H.; Soares-Filho, B. A Short Presentation of Dinamica EGO. In Geomatic Approaches for Modeling Land Change Scenarios; Camacho Olmedo, M.T., Paegelow, M., Mas, J.-F., Escobar, F., Eds.; Springer International Publishing: Cham, Switzerland, 2018; pp. 493-498.

59. Clarke, K.C. Land Use Change Modeling with SLEUTH: Improving Calibration with a Genetic Algorithm. In Geomatic Approaches for Modeling Land Change Scenarios; Camacho Olmedo, M.T., Paegelow, M., Mas, J.-F., Escobar, F., Eds.; Springer International Publishing: Cham, Switzerland, 2018; pp. 139-161.

60. Theobald, D. Landscape Patterns of Exurban Growth in the USA from 1980 to 2020. Ecol. Soc. 2005, 10, 1-35. Available online: http:/ / www.ecologyandsociety.org/vol10/iss1/art32/ (accessed on 30 August 2021). [CrossRef]

61. Verburg, P.H.; Veldkamp, A. Projecting land use transitions at forest fringes in the Philippines at two spatial scales. Landsc. Ecol. 2004, 19, 77-98. [CrossRef]

62. Sloan, S.; Pelletier, J. How accurately may we project tropical forest-cover change? A validation of a forward-looking baseline for REDD. Glob. Environ. 2012, 22, 440-453. [CrossRef]

63. Sleeter, B.M.; Wood, N.J.; Soulard, C.E.; Wilson, T.S. Projecting community changes in hazard exposure to support long-term risk reduction: A case study of tsunami hazards in the U.S. Pacific Northwest. Int. J. Disaster Risk Reduct. 2017, 22, 10-22. [CrossRef]

64. Yang, X.; Chen, R.; Zheng, X.Q. Simulating land use change by integrating ANN-CA model and landscape pattern indices Geomat. Nat. Hazards Risk 2016, 7, 918-932. [CrossRef]

65. Keshtkar, H.; Voigt, W. A spatiotemporal analysis of landscape change using an integrated Markov chain and cellular automata models. Modeling Earth Syst. Environ. 2016, 2, 1-13. [CrossRef]

66. Lu, Q.; Chang, N.-B.; Joyce, J.; Chen, A.S.; Savic, D.A.; Djordjevic, S.; Fu, G. Exploring the potential climate change impact on urban growth in London by a cellular automata-based Markov chain model. Comput. Environ. Urban. Syst. 2017, 68, 121-132. [CrossRef]

67. Id, M. Simulation and Prediction of Land Surface Temperature (LST) Dynamics within Ikom City in Nigeria Using Artificial Neural Network (ANN). J. Remote Sens. GIS 2015, 5, 1-7. [CrossRef]

68. Puertas, O.L.; Henríquez, C.; Meza, F.J. Assessing spatial dynamics of urban growth using an integrated land use model. Application in Santiago Metropolitan Area, 2010-2045. Land Use Policy 2014, 38, 415-425. [CrossRef]

69. Pahlavani, P.; Askarian Omran, H.; Bigdeli, B. A multiple land use change model based on artificial neural network, markov chain, and multi objective land allocation. Earth Obs. Geomat. Eng. 2017, 1, 82-99.

70. Tang, J.; Di, L. Past and Future Trajectories of Farmland Loss Due to Rapid Urbanization Using Landsat Imagery and the Markov-CA Model: A Case Study of Delhi, India. Remote Sens. 2019, 11, 180. [CrossRef]

71. Xie, Y.; Sha, Z.; Yu, M. Remote sensing imagery in vegetation mapping: A review. J. Plant. Ecol. 2008, 1, 9-23. [CrossRef]

72. Dewan, A.M.; Yamaguchi, Y. Land use and land cover change in Greater Dhaka, Bangladesh: Using remote sensing to promote sustainable urbanization. Appl. Geogr. 2009, 29, 390-401. [CrossRef] 
73. Storey, J.; Scaramuzza, P.; Schmidt, G. Landsat 7 Scan Line Corrector-Off Gap-Filled Product Development. In Proceedings of the Pecora 16 "Global Priorities in Land Remote Sensing", Sioux Falls, SD, USA, 23-27 October 2005.

74. Zhang, C.; Li, W.; Travis, D. Gaps-fill of SLC-off Landsat ETM+ satellite image using a geostatistical approach. Int. J. Remote Sens. 2007, 28, 5103-5122. [CrossRef]

75. Zhang, Q.; Yuan, Q.; Zeng, C.; Li, X.; Wei, Y. Missing Data Reconstruction in Remote Sensing Image With a Unified SpatialTemporal-Spectral Deep Convolutional Neural Network. IEEE Trans. Geosci. Remote Sens. 2018, 56, 4274-4288. [CrossRef]

76. Zhu, X.; Liu, D.; Chen, J. A new geostatistical approach for filling gaps in Landsat ETM+ SLC-off images. Remote. Sens. Environ. 2012, 124, 49-60. [CrossRef]

77. GoN. Topographical Map; Survey Department of Nepal: Kathmanu, Nepal, 1996.

78. Rimal, B.; Zhang, L.; Stork, N.; Sloan, S.; Rijal, S. Urban Expansion Occurred at the Expense of Agricultural Lands in the Tarai Region of Nepal from 1989 to 2016. Sustainability 2018, 10, 1341. [CrossRef]

79. Rimal, B.; Sharma, R.; Kunwar, R.; Keshtkar, H.; Stork, N.E.; Rijal, S.; Rahman, S.A.; Baral, H. Effects of land use and land cover change on ecosystem services in the Koshi River Basin, Eastern Nepal. Ecosyst. Serv. 2019, 38, 100963. [CrossRef]

80. Anderson, J.R.; Hardy, E.E.; Roach, J.T.; Witmer, R.E. A Land Use and Land Cover Classification System for Use with Remote Sensor Data; US Government Printing Office: Washington, DC, USA, 1976; Volume 964.

81. Steiner, D. Automation in photo interpretation. Geoforum 1970, 1, 75-88. [CrossRef]

82. Campbell, J.B.; Wynne, R.H. Introduction to Remote Sensing; The Guilford Press: New York, NY, USA, 2011.

83. Rodriguez-Galiano, V.F.; Ghimire, B.; Rogan, J.; Chica-Olmo, M.; Rigol-Sanchez, J.P. An assessment of the effectiveness of a random forest classifier for land-cover classification. ISPRS J. Photogramm. Remote Sens. 2012, 67, 93-104. [CrossRef]

84. Rimal, B.; Rijal, S.; Kunwar, R. Comparing Support Vector Machines and Maximum Likelihood Classifiers for Mapping of Urbanization. J. Indian Soc. Remote Sens. 2019, 48, 71-79. [CrossRef]

85. Kavzoglu, T.; Colkesen, I. A kernel functions analysis for support vector machines for land cover classification. Int. J. Appl. Earth Obs. Geoinf. 2009, 11, 352-359. [CrossRef]

86. Sarp, G.; Ozcelik, M. Water body extraction and change detection using time series: A case study of Lake Burdur, Turkey. J. Taibah Univ. Sci. 2018, 11, 381-391. [CrossRef]

87. Rimal, B.; Keshtkar, H.; Sharma, R.; Stork, N.; Rijal, S.; Kunwar, R. Simulating urban expansion in a rapidly changing landscape in eastern Tarai, Nepal. Environ. Monit. Assess. 2019, 191, 1-19. [CrossRef]

88. Niya, A.K.; Huang, J.; Kazemzadeh-Zow, A.; Karimi, H.; Keshtkar, H.; Naimi, B. Comparison of three hybrid models to simulate land use changes: A case study in Qeshm Island, Iran. Environ. Monit. Assess. 2020, 192, 1-19. [CrossRef]

89. Santé, I.; García, A.; Miranda, D.; Crecente Maseda, R. Cellular automata models for the simulation of real-world urban processes: A review and analysis. Landsc. Urban. Plan. 2010, 96, 108-122. [CrossRef]

90. Andaryani, S.; Sloan, S.; Nourani, V.; Keshtkar, H. The utility of a hybrid GEOMOD-Markov Chain model of land-use change in the context of highly water-demanding agriculture in a semi-arid region. Ecol. Inform. 2021, 64, 101332. [CrossRef]

91. Araya, Y.H.; Cabral, P. Analysis and Modeling of Urban Land Cover Change in Setúbal and Sesimbra, Portugal. Remote Sens. 2010, 2, 1549-1563. [CrossRef]

92. Kourosh Niya, A.; Huang, J.; Karimi, H.; Keshtkar, H.; Naimi, B. Use of Intensity Analysis to Characterize Land Use/Cover Change in the Biggest Island of Persian Gulf, Qeshm Island, Iran. Sustainability 2019, 11, 4396. [CrossRef]

93. Pontius, R.G.; Millones, M. Death to Kappa: Birth of quantity disagreement and allocation disagreement for accuracy assessment. Int. J. Remote Sens. 2011, 32, 4407-4429. [CrossRef]

94. Jensen, J.R. Introductory Digital Processing: A Remote Sensing Perspective; Prentice-Hall: Hoboken, NJ, USA, 1996.

95. Sexton, J.O.; Song, X.-P.; Huang, C.; Channan, S.; Baker, M.E.; Townshend, J.R. Urban growth of the Washington, D.C.-Baltimore, MD metropolitan region from 1984 to 2010 by annual, Landsat-based estimates of impervious cover. Remote Sens. Environ. 2013, 129, 42-53. [CrossRef]

96. Feng, Y.; Lu, D.; Moran, E.; Dutra, L.; Calvi, M.; de Oliveira, M. Examining Spatial Distribution and Dynamic Change of Urban Land Covers in the Brazilian Amazon Using Multitemporal Multisensor High Spatial Resolution Satellite Imagery. Remote Sens. 2017, 9, 381. [CrossRef]

97. Rai, R.; Neupane, P.; Dhakal, A. Is the contribution of community forest users financially efficient? A household level benefit-cost analysis of community forest management in Nepal. Int. J. Commons 2016, 10, 142-157. [CrossRef]

98. Tamrakar, P.R.; Mohans, B. Forest Restoration at Landscape Level in Nepal; Asia Pacific Forestry Commission: Kathmandu, Nepal, 2013.

99. Thapa, K.; Wikramanayake, E.; Malla, S.; Acharya, K.P.; Lamichhane, B.R.; Subedi, N.; Pokharel, C.P.; Thapa, G.J.; Dhakal, M.; Bista, A.; et al. Tigers in the Terai: Strong evidence for meta-population dynamics contributing to tiger recovery and conservation in the Terai Arc Landscape. PLoS ONE 2017, 12, e0177548. [CrossRef]

100. Jaquet, S.; Shrestha, G.; Kohler, T.; Schwilch, G. The Effects of Migration on Livelihoods, Land Management, and Vulnerability to Natural Disasters in the Harpan Watershed in Western Nepal. Mt. Res. Dev. 2016, 36, 494-505. [CrossRef]

101. Bhattarai, K.; Conway, D. The Environment. In Contemporary Environmental Problems in Nepal-Geographic Perspective; Springer Nature: Basingstoke, UK, 2021; pp. 115-199. [CrossRef]

102. Pokharel, B.K.; Byrne, S. Climate Change Mitigation and Adaptation Strategies in Nepal's Forest Sector: How Can Rural Communities Benefit? Rights and Resources Initiative: Washington, DC, USA, 2009. 
103. DFRS. Terai Forests of Nepal. Forest. Resource Assessment Nepal Project; Department of Forest Research and Survey: Kathmandu, Nepal, 2014.

104. Kandel, P.; Chapagain, P.S.; Sharma, L.N.; Vetaas, O.R. Consumption Patterns of Fuelwood in Rural Households of Dolakha District, Nepal: Reflections from Community Forest User Groups. Small-Scale For. 2016, 15, 481-495. [CrossRef]

105. Bhandari, R.; Pandit, S. Electricity as a Cooking Means in Nepal-A Modelling Tool Approach. Sustainability 2018, 10, 2841. [CrossRef]

106. Dhungana, S.P. REDD+ and Biodiversity Conservation; Dhakal, M., Lamichhane, D., Ghimire, M.D., Poudyal, A., Uprety, Y., Svich, T., Pandey, M., Eds.; Ministry of Forest and Environment (MoFE), Singhadurbar: Kathmandu, Nepal, 2018.

107. Baral, S.; Vacik, H. What Governs Tree Harvesting in Community Forestry-Regulatory Instruments or Forest Bureaucrats' Discretion? Forests 2018, 9, 649. [CrossRef]

108. REED. Preparation of Land Use Plans of Municipalities in and around the Emission Reduction Program Area: Cluster-2; REED: Babarmahal, Kathmandu, 2021.

109. MoFSC. Nepal REDD+ Strategy, Part 1: Operational Summary; Ministry of Forest and Soil Conservation (MoFSC): Kathmandu, Nepal, 2015.

110. Upreti, B.C.; Wollenberg, E.K.; Edmunds, D.; Buck, L.E.; Fox, J.; Brodt, S.B. Beyond Rhetorical Success: Advancing the Potential for the Community Forestry Programme in Nepal to Address Equity Concerns. In Social Learning in Community Forests; CIFOR: Bogor, Indonesia, 2001.

111. Banjade, M. Community Forestry and Local Development: Experiences from the Koshi Hills of Nepal. J. For. Livelihoods 2009, 8, 78-92. [CrossRef]

112. Rimal, B.; Rijal, S.; Stork, N.; Keshtkar, H.; Zhang, L. Forest restoration and support for sustainable ecosystems in the Gandaki Basin, Nepal. Environ. Monit. Assess. 2021, 193, 563. [CrossRef] [PubMed]

113. Baral, P.; Wen, Y.; Urriola, N.N. Forest Cover Changes and Trajectories in a Typical Middle Mountain Watershed of Western Nepal. Land 2018, 7, 72. [CrossRef]

114. Paudyal, K.; Baral, H.; Bhandari, S.P.; Bhandari, A.; Keenan, R.J. Spatial assessment of the impact of land use and land cover change on supply of ecosystem services in Phewa watershed, Nepal. Ecosystem Services 2019, 36, 100895. [CrossRef]

115. Ahammad, R.; Stacey, N.; Sunderland, T. Analysis of forest-related policies for supporting ecosystem services-based forest management in Bangladesh. Ecosyst. Serv. 2021, 48, 101235. [CrossRef] 